\title{
Deciphering the metamorphic evolution of the Pulo do Lobo metasedimentary domain (SW Iberian Variscides)
}

\author{
Irene Pérez-Cáceres ${ }^{1,2}$, David Jesús Martínez Poyatos ${ }^{1}$, Olivier Vidal $^{3}$, Olivier Beyssac ${ }^{4}$, Fernando Nieto $^{5}$, \\ José Fernando Simancas ${ }^{1}$, Antonio Azor ${ }^{1}$, and Franck Bourdelle ${ }^{6}$ \\ ${ }^{1}$ Departamento de Geodinámica, Facultad de Ciencias, Universidad de Granada, \\ Campus de Fuentenueva s/n, 18071 Granada, Spain \\ ${ }^{2}$ Instituto de Ciencias de la Tierra Jaume Almera ICTJA-CSIC, \\ C/Lluís Solé i Sabarís s/n, 08028 Barcelona, Spain \\ ${ }^{3}$ Institut de Sciences de la Terre (ISTerre), CNRS-University of Grenoble 1, \\ 1381 rue de la Piscine, 38041 Grenoble, France \\ ${ }^{4}$ Institut de Physique des Matériaux et de Cosmochimie (IMPMC), CNRS-Sorbonne Université, \\ Case Courrier 115, 4 place Jussieu, 75005 Paris, France \\ ${ }^{5}$ Departamento de Mineralogía y Petrología, IACT, Facultad de Ciencias, Universidad de Granada-CSIC, \\ Campus de Fuentenueva s/n, 18071 Granada, Spain \\ ${ }^{6}$ Univ. Lille, IMT Lille Douai, Univ. Artois, Yncrea Hauts-de-France, ULR 4515 - LGCgE, \\ Laboratoire de Génie Civil et géo-Environnement, 59000 Lille, France
}

Correspondence: Irene Pérez-Cáceres (perezcaceres@ugr.es)

Received: 20 September 2019 - Discussion started: 7 October 2019

Revised: 24 February 2020 - Accepted: 2 March 2020 - Published: 3 April 2020

\begin{abstract}
The Pulo do Lobo domain is one of the units exposed within the orogenic suture zone between the OssaMorena and the South Portuguese zones in the SW Iberian Variscides. This metasedimentary unit has been classically interpreted as a Rheic subduction-related accretionary prism formed during pre-Carboniferous convergence and eventual collision between the South Portuguese Zone (part of Avalonia) and the Ossa-Morena Zone (peri-Gondwanan terrane). Discrete mafic intrusions also occur within the dominant Pulo do Lobo metapelites, related to an intra-orogenic Mississippian transtensional and magmatic event that had a significant thermal input. Three different approaches have been applied to the Devonian-Carboniferous phyllites and slates of the Pulo do Lobo domain in order to study their poorly known low-grade metamorphic evolution. X-ray diffraction (XRD) was used to identify the mineralogy and measure crystallographic parameters (illite "crystallinity" and Kwhite mica $b$-cell dimension). Compositional maps of selected samples were obtained from electron probe microanalysis, which allowed for processing with XMapTools software, and chlorite semiempirical and thermodynamic
\end{abstract}

geothermometry was performed. Thermometry based on Raman spectroscopy of carbonaceous material (RSCM) was used to obtain peak temperatures.

The microstructural study shows the existence of two phyllosilicate growth events in the chlorite zone, the main one $\left(M_{1}\right)$ related to the development of a Devonian foliation $S_{1}$ and a minor one $\left(M_{2}\right)$ associated with a crenulation cleavage $\left(S_{2}\right)$ developed in middle-upper Carboniferous times. $M_{1}$ entered well into epizone (greenschist facies) conditions. $M_{2}$ conditions were at lower temperature, reaching the anchizone-epizone boundary. These data accord well with the angular unconformity that separates the Devonian and Carboniferous formations of the Pulo do Lobo domain. The varied results obtained by the different approaches followed, combined with microstructural analysis, provide different snapshots of the metamorphic history. Thus, RSCM temperatures are higher in comparison with the other methods applied, which is interpreted to reflect a faster re-equilibration during the short-lived thermal Mississippian event. Regarding the metamorphic pressure, the data are very homogeneous: very low celadonite content 
$(0 \%-10 \%)$ in muscovite (and low values of $\mathrm{K}$-white mica $b$-cell dimension; $8.995 \AA$ mean value), indicating a low pressure-temperature gradient, which is unexpected in a subduction-related accretionary prism.

\section{Highlights}

- A multidisciplinary approach has been applied to study the metamorphism of the Pulo do Lobo metapelites.

- Devonian metamorphism entered epizone conditions.

- Carboniferous metamorphism reached the anchizoneepizone boundary.

- The inferred low-pressure gradient is incompatible with a subduction-related accretionary prism.

\section{Introduction}

The determination of temperature and pressure $(P-T)$ conditions reached by the low-grade metasedimentary units stacked in the hinterlands of orogens constrains their tectonometamorphic evolution (e.g., Goffé and Velde, 1984; Franceschelli et al., 1986; Ernst, 1988; Gutiérrez-Alonso and Nieto, 1996; Frey and Robinson, 1999; Bousquet et al., 2008; Lanari et al., 2012). The various results derived from the application of diverse geothermometric and/or geobarometric methods may also allow for the identification and characterization of superposed tectonometamorphic events, thus improving the knowledge of $P-T$ paths and their tectonic significance (e.g., Brown, 1993; Crouzet et al., 2007; Ali, 2010; Lanari et al., 2012; Airaghi et al., 2017).

The metamorphism of the Iberian Variscides has been mostly studied on high-grade metamorphosed rocks in order to characterize and obtain the $P-T-t$ (pressuretemperature-time) paths of suture-related units (e.g., Gil Ibarguchi et al., 1990; Abalos et al., 1991; Escuder Viruete et al., 1994; Barbero, 1995; Arenas et al., 1997; Fonseca et al., 1999; López-Carmona et al., 2013; Martínez Catalán et al., 2014). The low- to very-low-grade units have been also studied (e.g., Martínez Catalán, 1985; Bastida et al., 1986, 2002; López Munguira et al., 1991; Gutiérrez-Alonso and Nieto, 1996; Abad et al., 2001, 2002, 2003a; Martínez Poyatos et al., 2001; Nieto et al., 2005; Vázquez et al., 2007), despite the scarcity of appropriate robust methodologies to apply in these kind of rocks. Obtaining new results from the low-grade rocks of the Pulo do Lobo domain, a suture-related low-grade unit in SW Iberia, is of prime importance in order to understand its significance and tectonometamorphic evolution, whose interpretations have been the cause of discrepancies, and to reconstruct the overall history of the SW Iberian Variscides.

In this work, three different methodologies are applied to a number of samples of the Pulo do Lobo domain (Fig. 1): (i) X-ray diffraction (XRD) in order to identify minerals not easily recognizable with optical microscopy (fine-grained muscovite, paragonite, mixed-layer phyllosilicates, etc.) and obtain thermobarometric information via the measurement of crystallographic parameters (illite crystallinity and $b$-cell dimension); (ii) compositional maps derived from electron probe microanalysis (EPMA), which enables the recognition of different tectonometamorphic events by combining mineral composition and microtextural features (e.g., Airaghi et al., 2017), as well as the application of geothermobarometers based on chlorite and K-white mica compositions; and (iii) Raman spectroscopy of carbonaceous material (RSCM) to estimate peak temperatures using an adapted thermometric calibration. The results obtained enable a discussion of the tectonometamorphic evolution of the Pulo do Lobo domain. Moreover, the comparison of the different approaches tests their reliability and sensitivity to characterize different geological processes.

\section{Geological setting}

The SW Iberian Variscides resulted from the DevonianCarboniferous left-lateral oblique collision of three different terranes: the Central Iberian Zone (CIZ), the OssaMorena Zone (OMZ), and the South Portuguese Zone (SPZ) (Fig. 1a); the boundaries between these terranes are considered orogenic sutures (e.g., Quesada, 1991; Pérez-Estaún et al., 2004; Pérez-Cáceres et al., 2016). Besides the dominant left-lateral shortening kinematics, SW Iberia also attests Mississippian synorogenic sedimentary basins, widespread mafic magmatism and high-temperature metamorphic areas, which together suggest an intra-orogenic transtensional stage (Simancas et al., 2003, 2006; Pereira et al., 2012; Azor et al., 2019).

The OMZ is commonly interpreted as a fragment of continental crust that drifted from the CIZ (i.e., north Gondwana) in early Paleozoic times (Matte, 2001). The OMZ-CIZ suture (Badajoz-Córdoba Shear Zone) includes early Paleozoic amphibolites with oceanic affinity, eclogite relicts, and intense high- to low-grade left-lateral shear deformation (Burg et al., 1981; Abalos et al., 1991; Quesada, 1991; Azor et al., 1994; Ordóñez-Casado, 1998; López Sánchez-Vizcaíno et al., 2003; Pereira et al., 2010). Ediacaran to Carboniferous sedimentary successions with an angular unconformity at the base of the lower Carboniferous characterize the OMZ. Lowgrade regional metamorphism dominates the OMZ, though there are areas of high-temperature and low-pressure metamorphism associated with early Carboniferous magmatism (e.g., Bard, 1977; Crespo-Blanc, 1991; Díaz Azpiroz et al., 2006; Pereira et al., 2009).

The SPZ is a continental piece considered to be a fragment of Avalonia, and thus the OMZ-SPZ boundary is usually interpreted as the Rheic Ocean suture (Crespo-Blanc and Orozco, 1988; Eden and Andrews, 1990; Silva et al., 1990; 

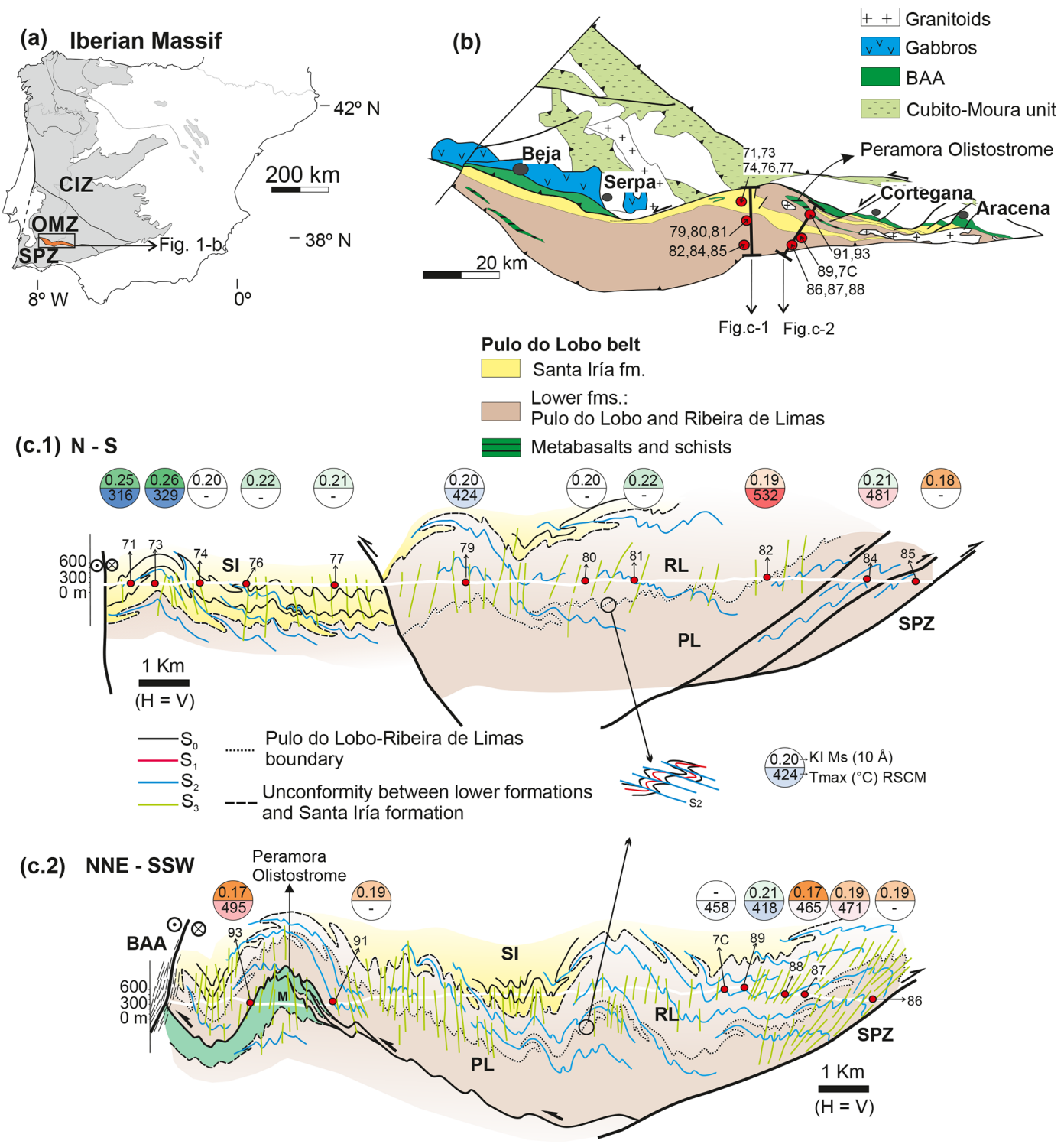

Figure 1. (a) Location of the studied area in the SW of the Iberian Massif (in grey). CIZ: Central Iberian Zone, OMZ: Ossa-Morena Zone, SPZ: South Portuguese Zone. (b) Geological map of the Pulo do Lobo domain and other units related to the OMZ-SPZ boundary with indications of the two cross sections studied and the samples collected. (c1-2) Geological cross sections of the Pulo do Lobo domain (see b for location) (modified from Martínez Poza et al., 2012; Pérez-Cáceres et al., 2015). Numbered red circles in (b)-(c) locate the samples studied. Big circles show the KI values for $10 \AA$ reflection peaks of K-white mica and the average RSCM temperatures, with the relative color bar according to the results shown in Table 1. BAA: Beja-Acebuches Amphibolites, M: metabasalts, PL: Pulo do Lobo Formation, RL: Ribeira de Limas Formation, SI: Santa Iría Formation.

Quesada et al., 1994; Braid et al., 2011; Pérez-Cáceres et al., 2015, 2017). This boundary is delineated by the BejaAcebuches Amphibolites (Fig. 1b), a narrow strip of metamafic rocks that resembles a dismembered ophiolitic succession (from greenschists to metagabbros and locally ultramafic rocks) (e.g., Bard, 1977; Crespo-Blanc, 1991; Quesada et al., 1994). This unit was interpreted as a Rheic ophiolite (Munhá et al., 1986; Crespo-Blanc, 1991; Fonseca and Ribeiro, 1993; Quesada et al., 1994; Castro et al., 1996). This idea was reconsidered based on the Mississippian age of the mafic protoliths ( $\approx 340 \mathrm{Ma}$; Azor et al., 2008) and is more likely evidence of the early Carboniferous intra-orogenic, lithospheric-scale transtensional and magmatic episode that obscures the previous suture-related features of the OMZSPZ boundary (Pérez-Cáceres et al., 2015, and references therein). Nevertheless, there is also the alternative explanation that the OMZ-SPZ boundary was a protected tract of Rheic oceanic lithosphere that did not close until Carboniferous times (Murphy et al., 2016; Braid et al., 2018; Quesada et al., 2019). The rocks of the Beja-Acebuches Amphibo- 
Table 1. Samples and results obtained by XRD ( $<2 \mu \mathrm{m}$ fraction), white mica and chlorite compositions, temperature ranges from chlorite thermometry, and average RSCM thermometry. Basel KI values and average RSCM temperatures show a relative color-bar scale. Mineral abbreviations according to Whitney and Evans (2010). Qz: quartz, Ms: muscovite, Fsp: feldspar, Chl: chlorite, Pg: paragonite, C-S: chlorite-smectite mixed layers, Cel: celadonite, Prl: pyrophyllite, Cli+Daph: clinochlore + daphnite, Am: amesite, Sud: sudoite, SD: standard deviation.

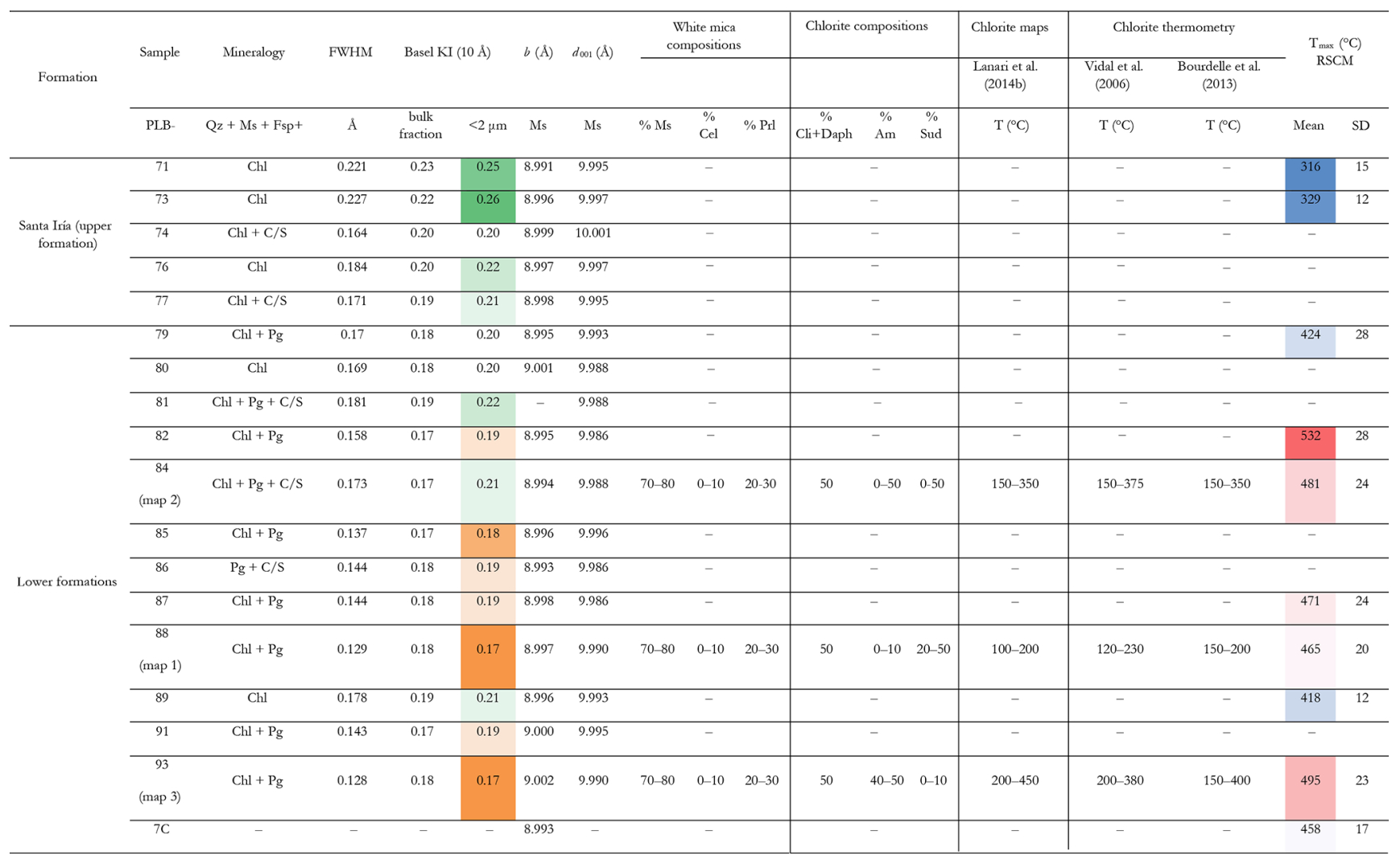

lites were affected by a left-lateral ductile shearing that occurred at granulite to greenschist facies conditions, though amphibolite facies conditions were dominant (e.g., Quesada et al., 1994; Castro et al., 1996, 1999; Díaz Azpiroz et al., 2006). This metamorphism has been dated at $345-330 \mathrm{Ma}$ (Dallmeyer et al., 1993; Castro et al., 1999), thus suggesting that it started very shortly after the magmatic emplacement.

North of the Beja-Acebuches Amphibolites, the allochthonous Cubito-Moura unit might be the only vestige of the Rheic Ocean suture (Fonseca et al., 1999; Araújo et al., 2005; Pérez-Cáceres et al., 2015). This unit was emplaced onto the southern OMZ border (Fig. 1b) with left-lateral top-to-the-ENE kinematics (Ponce et al., 2012). It contains Ediacaran-lower Paleozoic metasedimentary rocks and Ordovician MORB-featured mafic rocks $(\approx 480 \mathrm{Ma}$; Pedro et al., 2010) transformed into high-pressure blueschists and eclogites at $\approx 370 \mathrm{Ma}$ (Moita et al., 2005). The high-pressure metamorphism has also been studied by using white mica and chlorite (and chloritoid pseudomorphs) mineral equilibria (Booth-Rea et al., 2006; Ponce et al., 2012; Rubio Pascual et al., 2013), yielding peak conditions of $1 \mathrm{GPa}$ at $450^{\circ} \mathrm{C}$.
South of the Beja-Acebuches Amphibolites, low- to verylow-grade successions crop out: Devonian siliciclastics, earliest Carboniferous volcano-sedimentary rocks, and a southmigrating Carboniferous flysch (e.g., Oliveira, 1990). These rocks are usually grouped into two geological domains: the Pulo do Lobo domain to the north and the SPZs to the south (Fig. 1a, b). The deformation in the SPZ consists of a south- to southwest-vergent fold-and-thrust belt with decreasing strain intensity and age southwards (Oliveira, 1990; Simancas et al., 2004). The metamorphic grade also decreases southwards, from epizone to diagenetic, through the SPZ (Munhá, 1990; Abad et al., 2001). The Pulo do Lobo domain, which has been traditionally considered a suturerelated unit (see below), is the focus of this work.

\section{Pulo do Lobo domain}

The Pulo do Lobo domain constitutes a polydeformed structure affecting low-grade Devonian-Carboniferous sedimentary formations. These formations are the following, from bottom to top (Fig. 1b-c). 

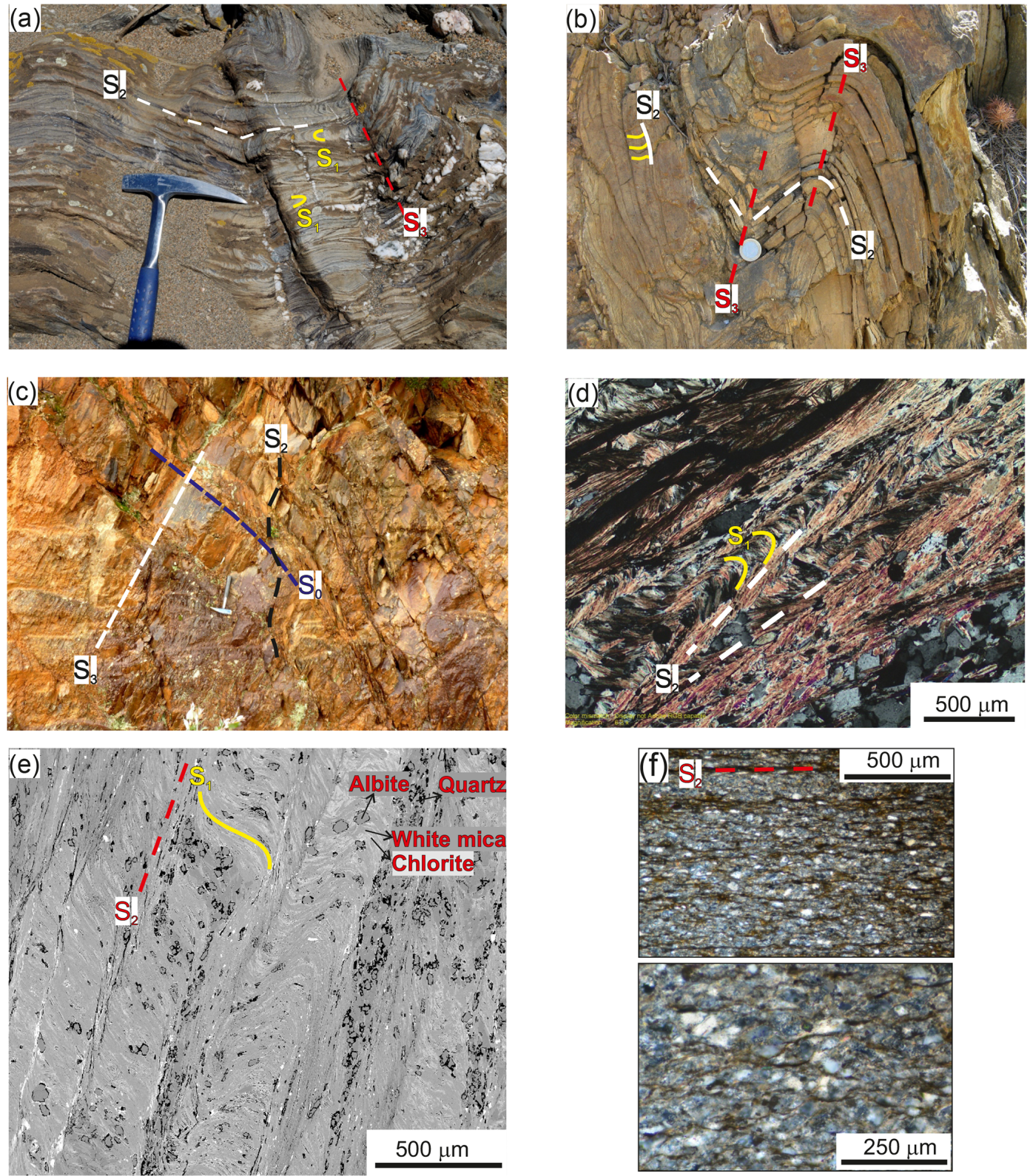

Figure 2. Pictures of the Pulo do Lobo rocks illustrating deformation at the outcrop scale: (a) Pulo do Lobo Formation, (b) Ribeira de Limas Formation, (c) Santa Iría Formation. Microphotographs from thin sections: (d) cross-polarized light image of sample PLB-84 (Pulo do Lobo Formation), (e) SEM-BSE (backscattered electron) image of sample PLB-88 (Ribeira de Limas Formation), (f) cross-polarized light images of sample PLB-71 (Santa Iría Formation).

i. The Pulo do Lobo Formation (sensu stricto) is constituted by a succession of satiny black to grey phyllites and fine-grained schists with minor intercalations of quartz sandstones (Fig. 2a). The presence of abundant segregated quartz veins (pre- to post-folding) is common. The palynological content suggests a middle Frasnian age (Pereira et al., 2018).

ii. The Ribeira de Limas Formation is constituted by phyllites with thin beds of quartz sandstones and arkoses
(Fig. 2b). The presence of palynomorphs also suggests a middle Frasnian age for this formation (Pereira et al., 2018). The contact with the underlying Pulo do Lobo Formation is gradual, with a progressive increase in sandstones and a decrease in phyllites upwards. For that reason, we will refer to the Pulo do Lobo and Ribeira de Limas formations as the lower formations of the Pulo do Lobo domain. Furthermore, these lower formations share the same structural fabrics consisting of three fold-related foliations (Fig. 2a-b; Pérez-Cáceres 
et al., 2015). The first foliation of the lower formations $\left(S_{1}\right)$ is preserved inside microlithons of the second foliation $\left(S_{2}\right)$; usually, the angle between these two foliations is high. $S_{2}$ is the main foliation and consists of a crenulation-dissolution cleavage that commonly appears as a millimetric- to centimetric-spaced tectonic banding. This foliation is axial-planar to north-vergent folds. The third foliation $\left(S_{3}\right)$ is a spaced crenulationdissolution cleavage that typically develops a characteristic decimetric- to metric-scale tectonic banding. $S_{3}$ is associated with upright to slightly south-vergent folds.

iii. The Santa Iría Formation is composed of alternating beds of slates and greywackes (Fig. 2c). The greywacke beds show normal grading and an erosive base. Paleontological and palynostratigraphic studies suggest an upper Famennian age for this formation (Pereira et al., 2008, 2018). However, an early Carboniferous age is also plausible, since more than $90 \%$ of the palynomorphs correspond to reworked material (Lopes et al., 2014) and the younger detrital zircon population is early Carboniferous (Braid et al., 2011; Pérez-Cáceres et al., 2017; Pereira et al., 2019). The Santa Iría Formation only shows two foliations, correlative with the last two deformation phases in the lower formations. Therefore, an unconformity between them is inferred, which is consistent with the age and flysch character of the Santa Iría Formation (Pérez-Cáceres et al., 2015). $S_{2}$ is observed as a penetrative slaty cleavage, while $S_{3}$ is a disjunctive crenulation cleavage.

According to Silva et al. (1990) and Pérez-Cáceres et al. (2015), the two main foliations $\left(S_{2}\right.$ and $\left.S_{3}\right)$ in the Pulo do Lobo domain resulted from the middle-upper Carboniferous collision between the OMZ and SPZ. The first foliation $\left(S_{1}\right)$ in the Pulo do Lobo domain might have formed during the convergence of the Rheic Ocean subduction and/or the beginning of the Variscan collision, probably at Late Devonian times.

The Pulo do Lobo domain contains some decimetric- to metric-scale lenticular bodies of MORB-featured metamafic rocks. At some outcrops, the mafic rocks are embedded in a greenish detrital matrix, thus suggesting an olistostromic origin (the Peramora Olistostrome; Eden and Andrews, 1990). These rocks are tectonically imbricated with the phyllites of the Pulo do Lobo Formation and hence form a tectonic mélange (the so-called Peramora Mélange; Fig. 1b-c; Eden, 1991; Dahn et al., 2014). Based on this aspect and on the supposedly Rheic Ocean derived greenschists, the Pulo do Lobo domain has been classically interpreted as a pre-collisional subduction-related accretionary prism (Eden and Andrews, 1990; Silva et al., 1990; Eden, 1991; Braid et al., 2010; Ribeiro et al., 2010; Dahn et al., 2014; Quesada et al., 2019). However, the recently obtained Mississippian U-Pb zircon ages from the metamafic rocks (Dahn et al., 2014; PérezCáceres et al., 2015) make it difficult to maintain such a hypothesis. More properly, they can be interpreted as mafic intrusions or extrusions in the frame of the intra-orogenic transtensional magmatic event that prevailed in SW Iberia during the Mississippian. The metamafic rocks display a foliation (equivalent to the $S_{2}$ of the enveloping metasediments) developed during loosely constrained greenschist facies metamorphism. These rocks would have been imbricated with the Pulo do Lobo metasedimentary rocks during the second deformation phase, which caused $S_{2}$ (PérezCáceres et al., 2015). Our multidisciplinary metamorphic study of the Pulo do Lobo metasediments provides crucial data concerning the tectonic significance of this domain.

\section{Samples and analytical methods}

A total of 18 samples were collected from well-exposed outcrops of phyllosilicate-rich detrital rocks of the Pulo do Lobo domain along two north-south transects perpendicular to the structural trend. Five samples belong to the Santa Iría Formation (unconformable upper formation) and 13 to the lower formations (Pulo do Lobo and Ribeira de Limas formations) (the locations of the samples are shown in the map and cross sections in Fig. 1b-c, and the UTM coordinates are given in the Supplement). As a whole, the samples were selected in fresh outcrops, far from faults and joints, and were as homogeneous and representative as possible. The sampling strategy was to collect representative sites, both of the overall stratigraphic succession and along two transects. We also aimed to characterize the unconformity between the lower and upper formations from a metamorphic point of view, since the crystallinity aspect to the naked eye appears to be lower in the Santa Iría Formation. Some samples from the lowermost Pulo do Lobo Formation were collected $\approx 200 \mathrm{~m}$ from the metabasite lenses of the Peramora Mélange.

Samples were examined under an optical microscope and scanning electron microscope (SEM) for overall mineralogy, deformation textures, and mineral-foliation relationships using an environmental scanning electron microscope FEI model Quanta 400 operating at $15-20 \mathrm{keV}$ (Centro de Instrumentación Científica, CIC, University of Granada, Spain).

\subsection{X-ray diffraction}

Sample preparation and analysis by XRD were done in the laboratories of the Department of Mineralogy and Petrology of the University of Granada (Spain). After washing and cleaning the patinas and oxides, samples were crushed to a $<2 \mathrm{~mm}$ fraction. The $<2 \mu \mathrm{m}$ fractions were separated by repeated extraction of supernatant liquid after centrifugation, according to the Stokes law. Oriented aggregates were prepared by sedimentation on glass slides of whole-rock and $<2 \mu \mathrm{m}$ fractions (the latter aims to minimize the content of detrital micas non-re-equilibrated during very-lowgrade metamorphism, which are generally larger than $2 \mu \mathrm{m}$; 
Moore and Reynolds, 1997). Samples were also treated with ethylene glycol (EGC) to identify illite-smectite or chloritesmectite mixed layers on the basis of their expandability. Samples were analyzed using a PANalytical X'Pert Pro powder diffractometer equipped with an X'Celerator detector, $\mathrm{CuK} \alpha$ radiation, operated at $45 \mathrm{kV}$ and $40 \mathrm{~mA}$, with an $\mathrm{Ni}$ filter and $0.25^{\circ}$ divergence slit. The resulting diffraction diagrams were examined to extract information on mineralogy based on their characteristic reflections and white mica crystal data.

The illite crystallinity index (Kübler index, KI; Kübler, 1968) has been estimated from the measurement of the full peak width of $\mathrm{K}$-white mica at half-maximum intensity (FWHM values), expressed as $\Delta^{\circ} 2 \theta$ of the Bragg angle. Preparation of samples and experimental conditions were carried out according to IGCP 294 IC Working Group recommendations (Kisch, 1991). A step increment of $0.008^{\circ} 2 \theta$ and a counting time of $52 \mathrm{~s}$ per step were used in the diffractometer. The KI was measured in all samples for both the 5 and $10 \AA$ reflection peaks of K-white mica in order to identify possible effects of other overlapping phases (Nieto and Sánchez-Navas, 1994; Battaglia et al., 2004). Some XRD traces showing complex mixtures of mixedlayer minerals were decomposed with the MacDiff software (Petschick, 2004). The FWHM values obtained in the laboratory $(x)$ were transformed to Crystallinity Index Standard (CIS) values $(y)$ using the equation $y=0.972 x+0.1096$ $\left(R^{2}=0.942\right)$, obtained from the measure in our laboratory of the international standards of Warr and Rice (1994). Finally, these values are expressed in terms of traditional KI values using the equation of Warr and Ferreiro Mähnlmann (2015; $\mathrm{CIS}=1.1523 \times$ Kübler index Basel lab +0.036$)$. The lower and upper boundaries of the anchizone in the KI scale are 0.42 and $0.25^{\circ} 2 \theta$, respectively (Warr and Ferreiro Mähnlmann, 2015). The thermal range for the anchizone is estimated as $200-300^{\circ} \mathrm{C}$, though the $\mathrm{KI}$ cannot be considered a true geothermometer (Frey, 1987; Kisch, 1987).

The $b$-cell parameter of white mica was obtained from the (060) reflection peak measured with quartz as an internal standard on polished rock slices cut normal to the sample main foliation $S_{2}$ (Sassi and Scolari, 1974). The $b$-cell dimension of $\mathrm{K}$-white mica is typically proportional to the extent of phengitic substitution and is therefore considered a proxy for the pressure conditions during its crystallization. Thus, Guidotti and Sassi (1986) have shown that $b$ values lower than $9.000 \AA$ are typical of low-pressure facies conditions, while $b$ values higher than $9.040 \AA$ are related to relatively high-pressure facies metamorphism. Precise measurements of the basal spacing of white mica $\left(d_{001}\right)$ have also been made using quartz from the sample itself as an internal standard; $d_{001}$ is related to the paragonitic $\mathrm{Na} / \mathrm{K}$ substitution (Guidotti et al., 1992), thereby approximately reflecting the temperature of white mica formation (Guidotti et al., 1994).

\subsection{EPMA-derived X-ray compositional maps and chlorite thermometry}

From all of the collected samples, we selected those with the larger phyllosilicate grain size for electron probe microanalysis (EPMA). Thus, three carbon-coated polished thin sections were studied. The selected samples (PLB-84, PLB-88, and PLB-93) belong to the lower formations of the Pulo do Lobo domain (Fig. 2d-e). The Santa Iría samples could not be studied due to the tiny grain size of the minerals (commonly less than $3 \mu \mathrm{m}$ ).

Compositional maps and accurate spot analyses were performed on a JEOL JXA-8230 EPMA at the Institut des Sciences de la Terre (ISTerre) in Grenoble (France), according to the analytical procedure proposed by De Andrade et al. (2006) and Lanari et al. (2014a). The data acquisition was made in wavelength-dispersive spectrometry mode (WDS), 10 elements ( $\mathrm{Si}, \mathrm{Ca}, \mathrm{Al}, \mathrm{K}, \mathrm{Mn}, \mathrm{Na}, \mathrm{P}, \mathrm{Ti}, \mathrm{Fe}$, and $\mathrm{Mg}$ ) were analyzed using five WD spectrometers: TAP crystal for $\mathrm{Si}$ and $\mathrm{Al}$, PETL for Ti and $\mathrm{P}$, TAPH for $\mathrm{Na}$ and $\mathrm{Mg}$, PETH for $\mathrm{K}$ and $\mathrm{Ca}$, and LIFH for Mn and Fe. The standardization was made by using certified natural minerals and synthetic oxides: wollastonite $(\mathrm{Si}, \mathrm{Ca})$, corundum $(\mathrm{Al})$, orthoclase $(\mathrm{K})$, rhodonite $(\mathrm{Mn})$, albite $(\mathrm{Na})$, apatite $(\mathrm{P})$, rutile $(\mathrm{Ti})$, hematite $(\mathrm{Fe})$, and periclase $(\mathrm{Mg})$. X-ray maps were obtained by adding successive adjacent profiles. A beam current of $100 \mathrm{nA}$ and a beam size spot (focused) were used. The step (pixel) size was $1 \mu \mathrm{m}$ and the dwell time was 200 $300 \mathrm{~ms}$ per pixel. Spot analyses were conducted along the profiles within the mapping at $15 \mathrm{kV}$ accelerating voltage, $12 \mathrm{nA}$ beam current, and $2 \mu \mathrm{m}$ beam size spot (focused). The on-peak counting time was $30 \mathrm{~s}$ for each element and $30 \mathrm{~s}$ for two background measurements at either side of each peak. A ZAF correction procedure was applied. The internal standards were orthoclase and/or chromium-augite (Jarosewich et al., 1980), which were run (three points on each standard) after each profile in order to monitor instrumental drift and estimate analytical accuracy. Drift correction was made, if necessary, using the corresponding regression equation.

The WDS X-ray maps were then processed with XMapTools (http://www.xmaptools.com, last access: 10 September 2009), a MATLAB-based graphical user interface program to process the chemical maps, link them to thermobarometric models, and estimate the pressure-temperature conditions of the crystallization of minerals in metamorphic rocks (Lanari et al., 2014a). The compositional maps were standardized with the spot analyses measured along the profiles and mineral compositions were plotted into binary and ternary diagrams using the interface modules Chem2D and Triplot3D. Chemical maps of the amount of tetrahedral aluminum $\left(\mathrm{Al}^{\mathrm{IV}}\right)$ in chlorites were acquired because these amounts are used in many empirical chlorite thermometers (e.g., Cathelineau and Nieva, 1985; Cathelineau, 1988). The temperature conditions were estimated for each chlorite pixel of the maps using the chlorite thermometer of Lanari et 
al. (2014b), as well as the approaches of Vidal et al. (2006) and Bourdelle et al. (2013), which are summarized in the Supplement.

In addition to the abovementioned compositional maps, white micas from seven carbon-coated thin sections of the lower formations of the Pulo do Lobo domain were analyzed before with a JEOL WDS four-spectrometer microprobe (JXA-8200 Superprobe) at the University of Huelva (Spain). A combination of silicates and oxides was used for calibration: standards used were wollastonite $(\mathrm{Si}$ and $\mathrm{Ca}$ ), potassium feldspar ( $\mathrm{Al}, \mathrm{K}$, and $\mathrm{Na}$ ), forsterite $(\mathrm{Mg})$, and fayalite (Fe). Single-point analyses were conducted with $20 \mathrm{nA}$ probe current, $1-5 \mu \mathrm{m}$ spot size, and $15 \mathrm{kV}$ of acceleration voltage, with $5 \mathrm{~s}$ counting times.

\subsection{Raman spectroscopy of carbonaceous material}

Raman spectroscopy of carbonaceous material (RSCM) is based on the observation that sedimentary carbonaceous material $(\mathrm{CM})$ is progressively transformed into graphite at increasing temperature. Because of the irreversible character of graphitization, CM structure is not sensitive to the retrograde path during the exhumation of rocks, but it depends only on the maximum temperature reached during metamorphism (Beyssac et al., 2002a). Temperature was determined in the range $330-650^{\circ} \mathrm{C}$ with a calibration-attached accuracy of $\pm 50^{\circ} \mathrm{C}$ due to uncertainties in the petrologic data used for the calibration (Beyssac et al., 2002a). Relative uncertainties in temperature estimates were later reduced (around 10$15^{\circ} \mathrm{C}$; Beyssac et al., 2004). For temperature below $330^{\circ} \mathrm{C}$, Lahfid et al. (2010) performed a systematic study of the evolution of the Raman spectrum of CM in low-grade metamorphic rocks in the Glarus Alps (Switzerland). They showed that the Raman spectrum of CM is slightly different from the spectrum observed at higher temperature, and they established a quantitative correlation between the degree of structuration of $\mathrm{CM}$ and temperature.

In this work, 12 representative thin sections previously examined by optical microscopy were selected. From these, 10 samples were analyzed (according to their larger CM grain size and content): eight samples belong to the lower Pulo do Lobo and Ribeira de Limas formations, and the other two samples belong to the Santa Iría Formation. Polished thin sections cut perpendicularly to the $S_{2}$ foliation were analyzed at the Institut de Minéralogie, de Physique des Matériaux et de Cosmochimie at the Sorbonne University of Paris (France). We closely followed the analytical procedure described by Beyssac et al. (2002a, b; 2003; see the Supplement). More than 15 Raman spectra (Fig. 3) were obtained for each sample using a Renishaw InVIA Reflex microspectrometer equipped with a $514.5 \mathrm{~nm}$ Modulaser argon laser under circular polarization. The laser was focused by a DMLM Leica microscope, and laser power was set below $1 \mathrm{~mW}$ at the sample surface. The Rayleigh diffusion was eliminated by edge filters, and the signal was dispersed using a $1800 \mathrm{~g} \mathrm{~mm}^{-1}$ grating and finally analyzed by a Peltier cooled RENCAM CCD detector. The recorded spectral window was large enough to precisely determine the background correction, from 700 to $2000 \mathrm{~cm}^{-1}$ in the case of low-temperature samples. Before each session, the spectrometer was calibrated with a silicon standard. CM was systematically analyzed behind a transparent adjacent mineral, generally quartz or white mica grains oriented along $S_{1}$. For a full description of the temperature calculations see the Supplement.

\section{Results}

According to the petrographic study, all the samples correspond to slates or phyllites with phyllosilicates smaller than $500 \mu \mathrm{m}$, composed of variable quartz $+\mathrm{K}$ white mica \pm chlorite \pm feldspar \pm ore and accessory minerals (Fig. 2d-f). Samples from the Santa Iría Formation have a much smaller grain size and apparently lower crystallinity (Fig. 2f). The first foliation $S_{1}$ is defined by the largest micas and chlorites (Fig. 2d-e), being folded by microscopic- to centimetric-scale tight folds of the second deformation phase (Fig. 2a-b, d-e). The second foliation $S_{2}$ is the main foliation at outcrop (Fig. 2a-c), but the phyllosilicates (mostly white mica) are smaller than those in $S_{1}$. The third foliation $S_{3}$ is a fracture cleavage that does not develop phyllosilicates (Fig. 2a-c).

\subsection{X-ray diffraction}

The mineralogy and crystal parameters of K-white mica obtained from the 18 samples of the Pulo do Lobo domain are summarized in Table 1 . The results of KI values, the $b$ cell parameter, and $d_{001}$ analyzed in K-white mica obtained from whole-rock and $<2 \mu \mathrm{m}$ fractions are very similar, which suggests that detrital micas re-equilibrated during metamorphism.

The mineralogy of the samples is relatively simple: $\mathrm{Qz}+\mathrm{Ms}+\mathrm{Fsp}+\mathrm{Chl} \pm \mathrm{Pg} \pm \mathrm{C}-\mathrm{S}$. The slates of the Santa Iría Formation have quartz, muscovite, and chlorite, with chlorite-smectite $(\mathrm{C}-\mathrm{S})$ interlayers in some samples. In the lower formations, besides quartz and muscovite, chlorite is present in almost all of the samples, paragonite appears in most of them, and chlorite-smectite interlayers are occasional.

KI values measured in the $10 \AA$ peak of white mica from the $<2 \mu \mathrm{m}$ fraction are shown in Table 1 and Fig. 1c with a relative color bar from orange (lower values) to green (higher values). Values of the Santa Iría samples $(n=5)$ range from 0.20 to $0.26 \Delta^{\circ} 2 \theta$, and the mean value is 0.23 (standard deviation 0.02 ). In the lower formations ( $n=12$ ), KI values range from 0.17 to 0.22 , and the mean value is 0.19 (standard deviation 0.02 ). KI values measured in the $5 \AA$ peak (not shown to avoid repetition) are very similar to those of the $10 \AA$ peak. 

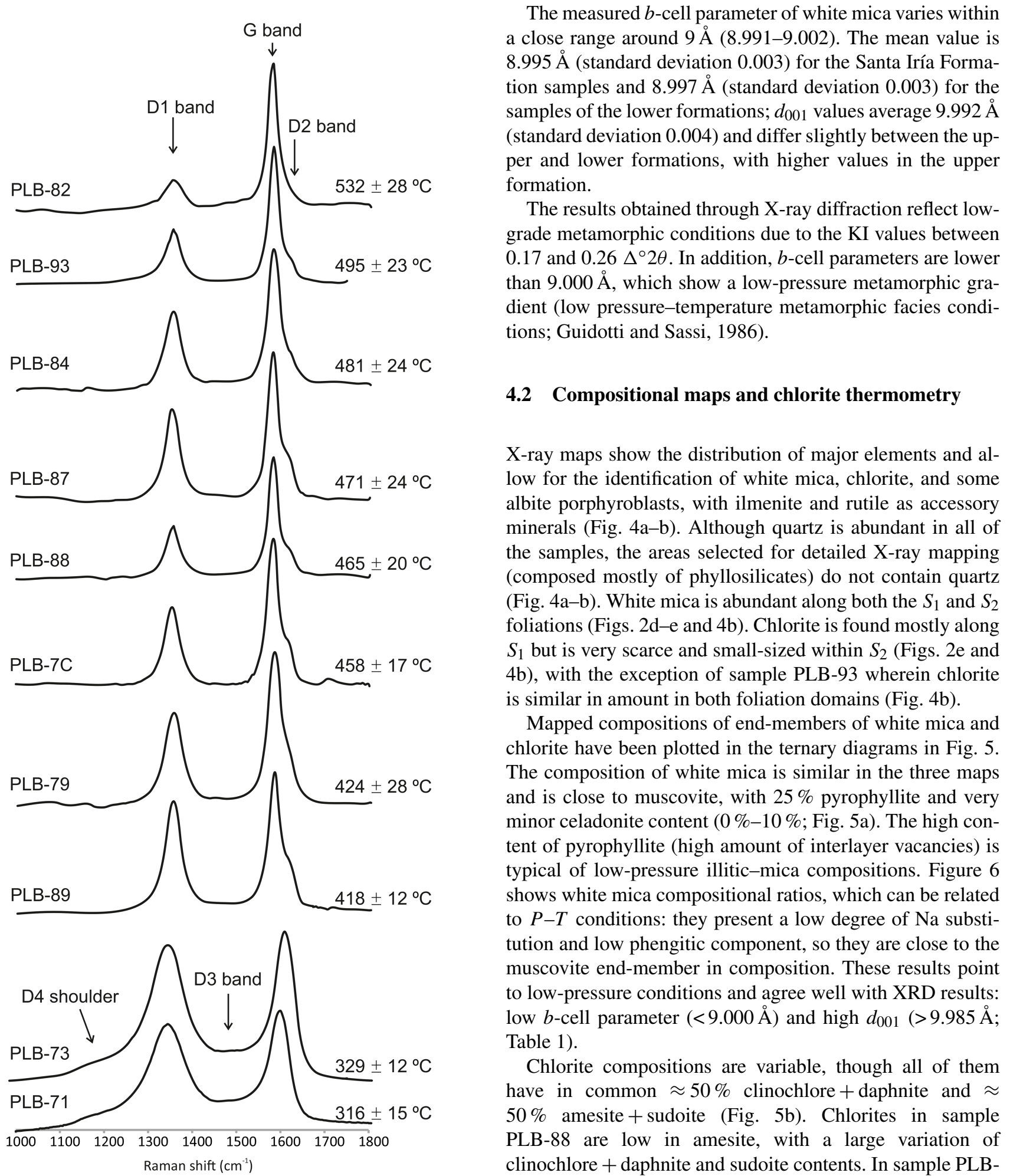

Figure 3. Representative Raman spectra of CM across the Pulo do Lobo domain from low temperature (bottom; Santa Iría Formation) to high temperature (top; lower formations) including the average maximum temperatures $\left({ }^{\circ} \mathrm{C}\right)$ for each sample. The vertical scale for spectrum intensity is arbitrary. See Fig. 1 for the sample location and Table 1 and the Supplement for RSCM data.
The measured $b$-cell parameter of white mica varies within a close range around $9 \AA$ (8.991-9.002). The mean value is $8.995 \AA$ (standard deviation 0.003) for the Santa Iría Formation samples and $8.997 \AA$ (standard deviation 0.003) for the samples of the lower formations; $d_{001}$ values average $9.992 \AA$ (standard deviation 0.004) and differ slightly between the upper and lower formations, with higher values in the upper formation.

The results obtained through X-ray diffraction reflect lowgrade metamorphic conditions due to the KI values between 0.17 and $0.26 \Delta^{\circ} 2 \theta$. In addition, $b$-cell parameters are lower than $9.000 \mathrm{~A}$, which show a low-pressure metamorphic grations; Guidotti and Sassi, 1986).

\subsection{Compositional maps and chlorite thermometry}

X-ray maps show the distribution of major elements and allow for the identification of white mica, chlorite, and some albite porphyroblasts, with ilmenite and rutile as accessory minerals (Fig. 4a-b). Although quartz is abundant in all of the samples, the areas selected for detailed X-ray mapping (composed mostly of phyllosilicates) do not contain quartz (Fig. 4a-b). White mica is abundant along both the $S_{1}$ and $S_{2}$ foliations (Figs. 2d-e and 4b). Chlorite is found mostly along $S_{1}$ but is very scarce and small-sized within $S_{2}$ (Figs. 2e and 4b), with the exception of sample PLB-93 wherein chlorite is similar in amount in both foliation domains (Fig. 4b).

Mapped compositions of end-members of white mica and chlorite have been plotted in the ternary diagrams in Fig. 5. The composition of white mica is similar in the three maps and is close to muscovite, with $25 \%$ pyrophyllite and very minor celadonite content ( $0 \%-10 \%$; Fig. 5a). The high content of pyrophyllite (high amount of interlayer vacancies) is typical of low-pressure illitic-mica compositions. Figure 6 shows white mica compositional ratios, which can be related to $P-T$ conditions: they present a low degree of Na substitution and low phengitic component, so they are close to the muscovite end-member in composition. These results point to low-pressure conditions and agree well with XRD results: low $b$-cell parameter $(<9.000 \AA)$ and high $d_{001}(>9.985 \AA$; Table 1).

Chlorite compositions are variable, though all of them have in common $\approx 50 \%$ clinochlore + daphnite and $\approx$ $50 \%$ amesite + sudoite (Fig. 5b). Chlorites in sample PLB-88 are low in amesite, with a large variation of clinochlore + daphnite and sudoite contents. In sample PLB84 , chlorites vary in composition between amesite and sudoite, indicating a variation of $\mathrm{Al}^{\mathrm{IV}}$, which implies an increase in temperature from rims to cores as shown in the chemical maps in Fig. 4c. Finally, PLB-93 chlorites are poor average temperatures (Vidal et al., 2006) than in PLB-84 and PLB-88. Altogether, the chlorite compositional data show the in sudoite and higher in $\mathrm{Al}^{\mathrm{IV}}$ content, thus suggesting higher 
MAP 1: PLB-88

(a)

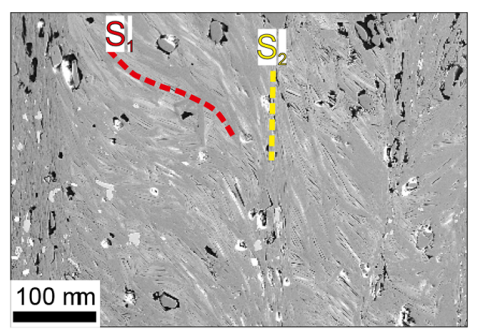

(b)

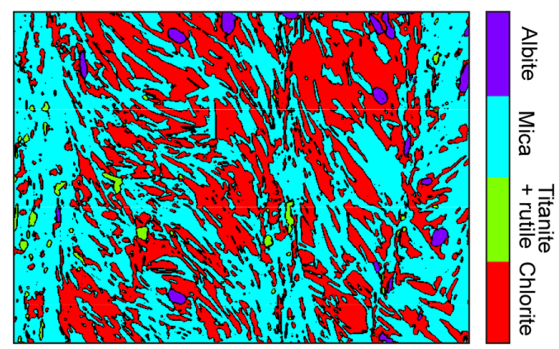

MAP 2: PLB-84
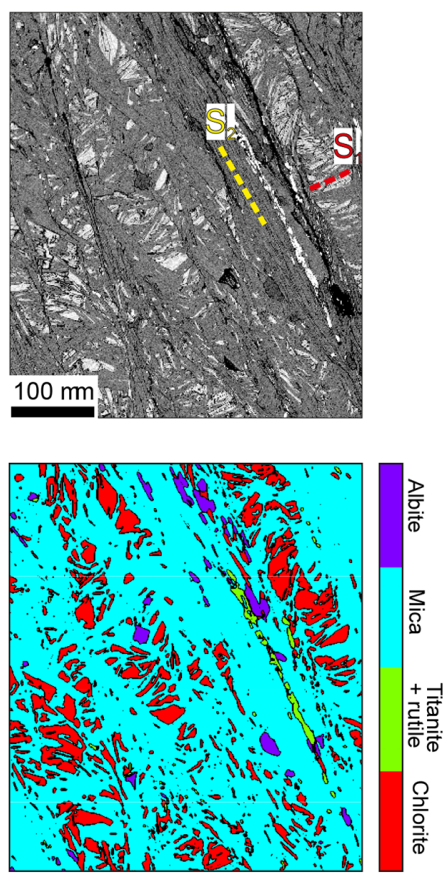

(c)
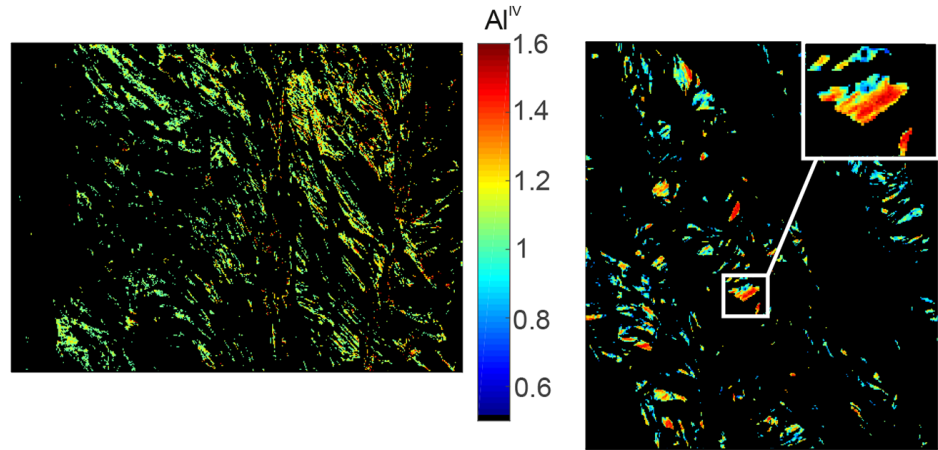

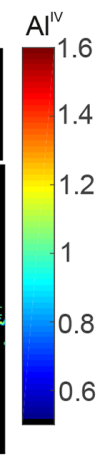

MAP 3: PLB-93
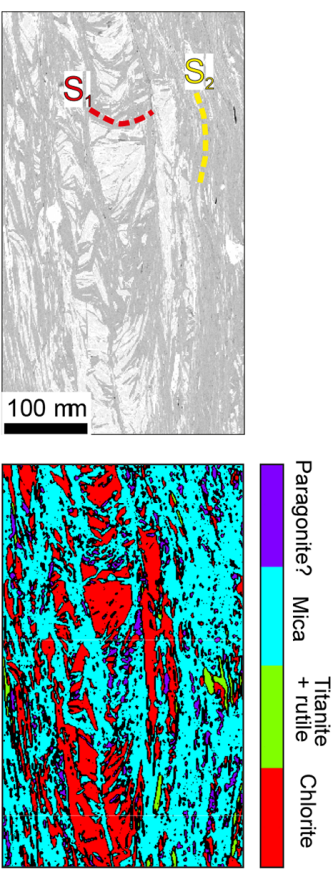

(d)

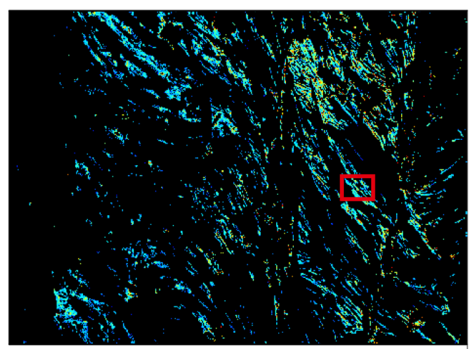

Temp $\left({ }^{\circ} \mathrm{C}\right)$
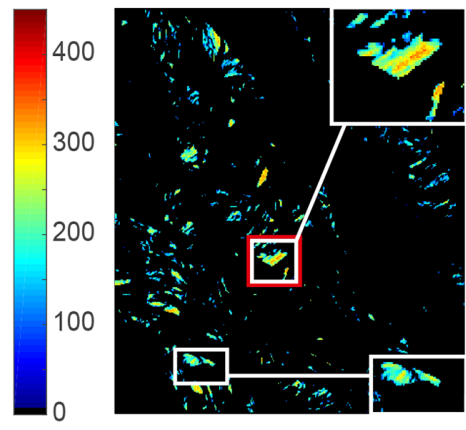

Temp $\left({ }^{\circ} \mathrm{C}\right)$
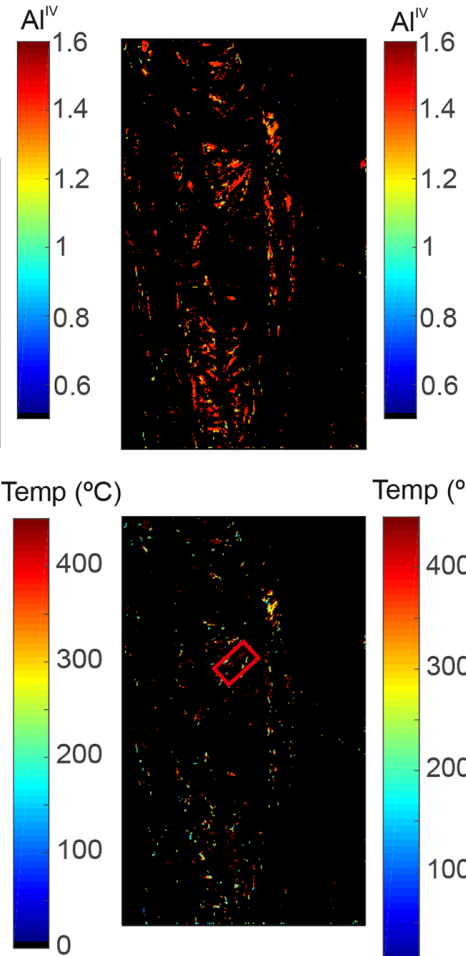

Temp $\left({ }^{\circ} \mathrm{C}\right)$

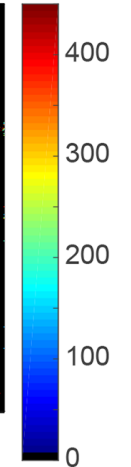

Figure 4. X-ray maps of the three selected samples analyzed by EPMA and processed with XMapTools. The samples belong to the lower formations of the Pulo do Lobo domain (sample PLB-88: Ribeira de Limas Formation; samples PLB-84 and PLB-93: Pulo do Lobo Formation; the latter (PLB-93) is close to early Carboniferous igneous intrusions). (a) EPMA BSE photographs. (b) Mineral maps. (c) $\mathrm{Al}^{\mathrm{IV}}$ content map in chlorites, which increases with temperature. The white square highlights the zonation of a chlorite grain from core to rim. (d) Temperature maps of chlorite using the Lanari et al. (2014a) geothermometer assuming all iron as ferrous. White squares show selected areas illustrating higher-temperature chlorite cores. Red squares show the selected areas (representative of $S_{1}$ foliation) used for the chlorite-quartz-water geothermometric calculations shown in Fig. 7. 
MAP 1: PLB-88

(a)
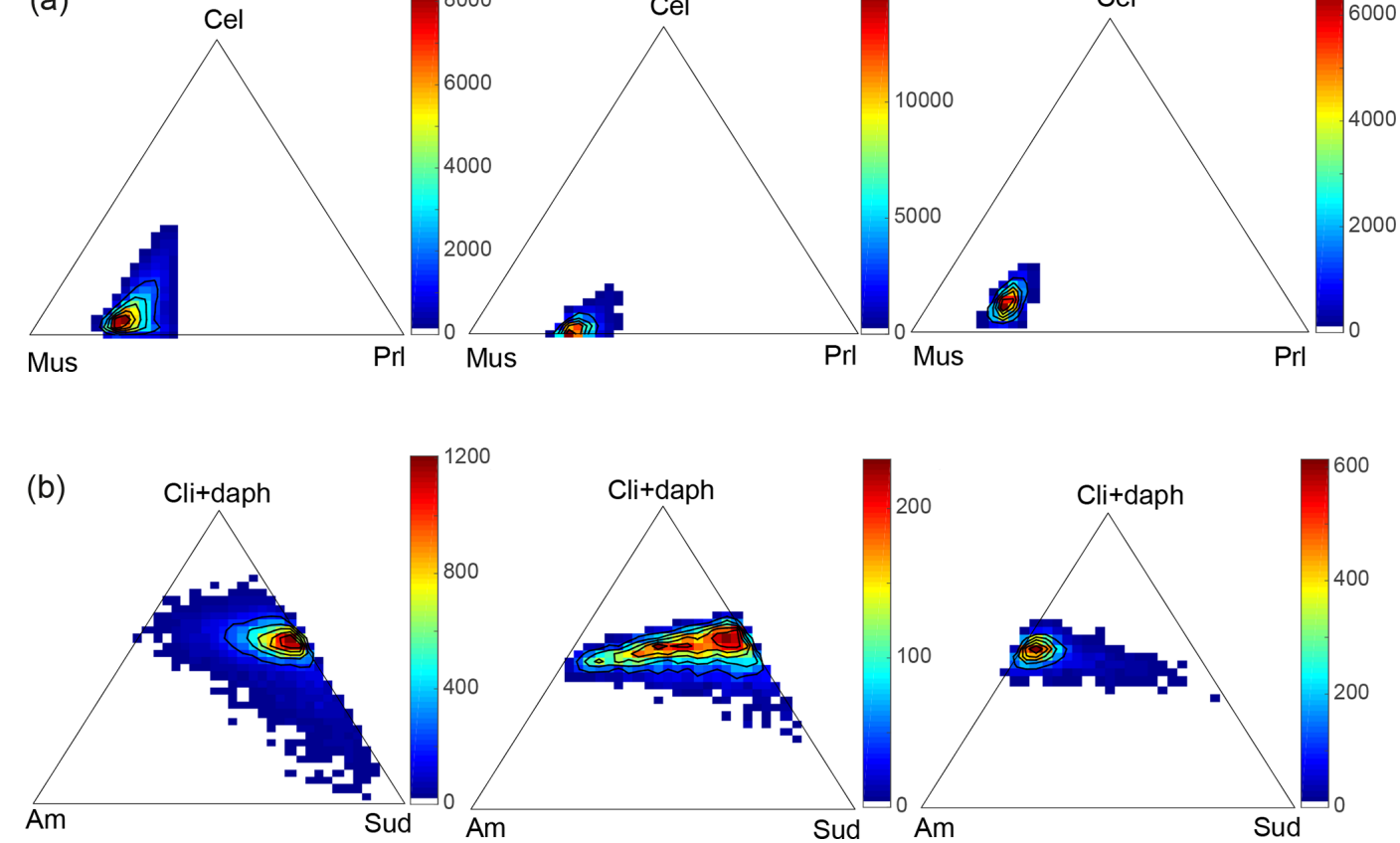

Figure 5. Ternary plots of all the analyzed white micas (a) (Cel: celadonite, Mus: muscovite, Prl: pyrophyllite) and chlorite (b) (Cli + Daph: clinochlore + daphnite, Am: amesite, Sud: sudoite) plotted with the XMapTools TriPlot3D module. Color bars refer to the number of micachlorite pixels analyzed.

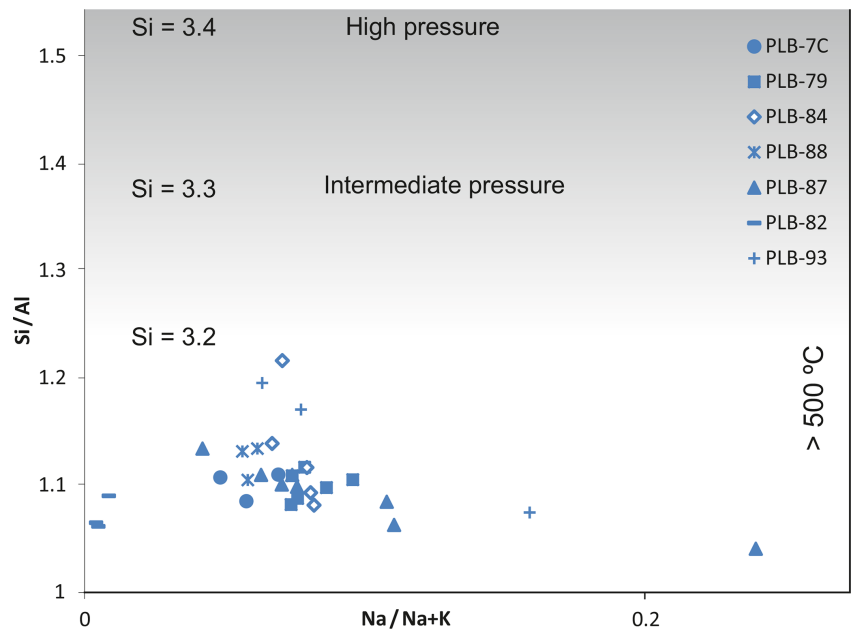

Figure 6. Compositional diagram of white micas showing $\mathrm{Na} / \mathrm{Na}+$ $\mathrm{K}$ vs. Si/Al (atomic ratios) for 31 EPMA point analyses from seven samples of the lower formations of the Pulo do Lobo domain (different symbology for each sample). Point analyses were conducted on the microprobe at the University of Huelva (Spain). Qualitative information about temperature and pressure conditions is respectively according to Guidotti et al. (1994), Coggon and Holland (2002), Parra et al. (2002), Massonne and Schereyer (1987), and Massonne and Szpurka (1997). presence of two end-members: sudoite-rich low temperature (PLB-88) and amesite-rich high temperature (PLB-93).

Maps of $\mathrm{Al}^{\mathrm{IV}}$ in chlorites are displayed in Fig. 4c. Sample PLB-88 displays lower $\mathrm{Al}^{\mathrm{IV}}$ content $(\approx 1.1-1.3 \mathrm{apfu})$ than sample PLB-93 $(\approx 1.3-1.5$ apfu $)$. In sample PLB-84, some large chlorite grains oriented along $S_{1}$ are zoned, with higher $\mathrm{Al}^{\mathrm{IV}}$ content in the cores $(\approx 1.4 \mathrm{apfu})$ than in the rims $(\approx 1.0 \mathrm{apfu}$; see the white square in Fig. $4 \mathrm{c})$. According to the empirical calibration of Cathelineau (1988), $\mathrm{Al}^{\mathrm{IV}}$ in chlorites increases with temperature. Thus, the $\mathrm{Al}^{\mathrm{IV}}$ content in chlorites manifests different temperatures in different samples and also varies from core to rim in singular grains.

Temperature maps have been obtained with the semiempirical thermometer of Lanari et al. (2014b), which assumes that $\mathrm{Fe}^{2+}$ is the $\mathrm{Fe}$ total (Fig. 4d). Temperatures range between 100 and $200^{\circ} \mathrm{C}$ in sample PLB-88, between 150 and $350^{\circ} \mathrm{C}$ in sample PLB-84, and between 200 and $450^{\circ} \mathrm{C}$ in sample PLB-93. Tiny chlorites developed along $S_{2}$ yield lower temperatures than larger and more abundant chlorites along $S_{1}$, with the exception of sample PLB-93. Furthermore, some large chlorites oriented along $S_{1}$ are zoned, showing high-temperature relic cores $\left(350-450{ }^{\circ} \mathrm{C}\right.$; see white insets in Fig. 4c-d) surrounded by low-temperature rims (150$\left.250^{\circ} \mathrm{C}\right)$.

To test the Vidal et al. $(2005,2006)$ and Bourdelle et al. (2013) thermometers, an area of representative chlorites in an $S_{1}$ microlithon was selected from each map (see red insets 
(a) MAP 1: PLB-88

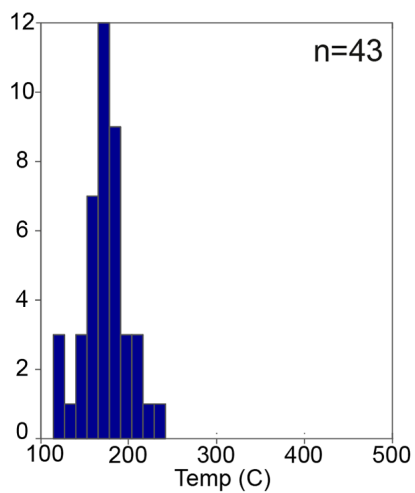

(b)

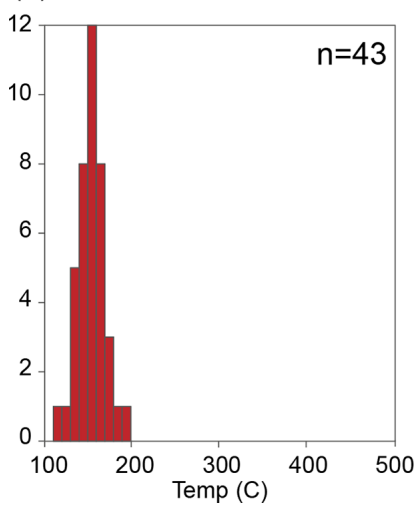

MAP 2: PLB-84
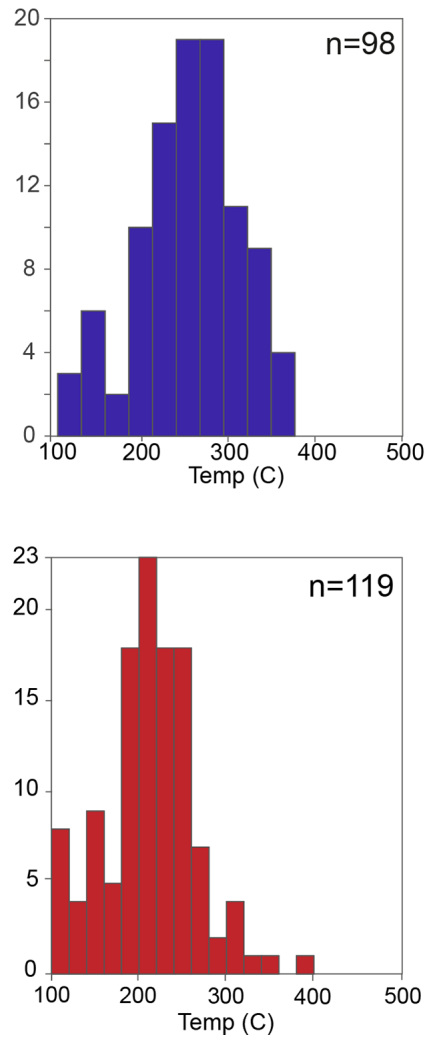

MAP 3: PLB-93
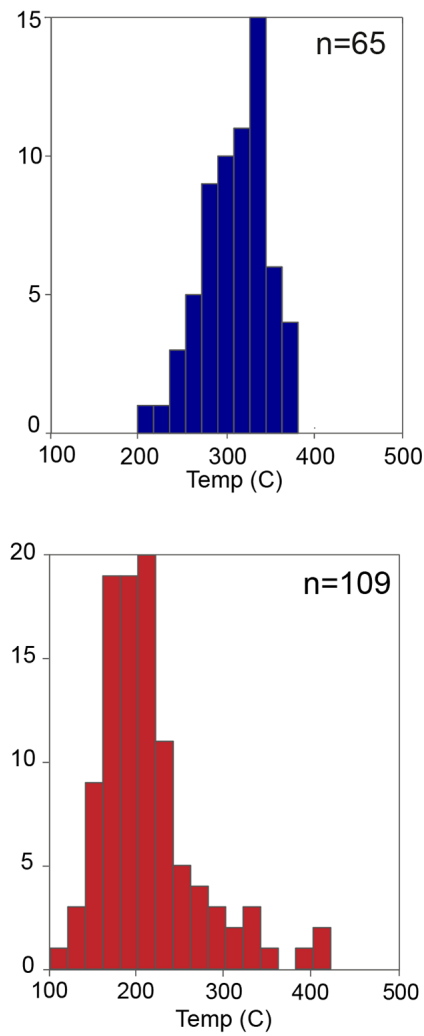

Figure 7. Histograms of temperatures obtained using the chlorite-quartz-water geothermometer of Vidal et al. (2006) (a) and Bourdelle et al. (2013) (b) on selected representative $S_{1}$ chlorites (see the red squares in Fig. $4 \mathrm{~d}$ for location); $n$ represents the number of chlorites that could be used for each calibration. The number of analyses is lower in those with the Vidal et al. (2006) approach because of the assumption that the Si content of chlorite is lower than 3 apfu.

in Fig. 4d). Corresponding chlorite compositions were extracted and introduced in the chlorite-quartz-water equilibria (Fig. 7a; Vidal et al., 2005, 2006; Fig. 7b, Bourdelle et al., 2013). The temperature estimates (Fig. 7) derived from both methods are fairly similar, averaging $120-230^{\circ} \mathrm{C}$ in sample PLB- 88 and $150-380^{\circ} \mathrm{C}$ in sample PLB-84. These estimates are also in agreement with the estimates derived from temperature maps calculated with the Lanari et al. (2014a) model. Only sample PLB-93 shows a divergence on temperature averages: mostly $150-250^{\circ} \mathrm{C}$ with the thermometer of Bourdelle et al. (2013) and $250-350^{\circ} \mathrm{C}$ with that of Vidal et al. (2005, 2006). In both cases (Bourdelle et al., 2013 and Vidal et al, 2005, 2006 methods), the higher-temperature analysis results are obtained from crystal cores in sample PLB-93.

\subsection{RSCM thermometry}

The ratio parameters and corresponding maximum temperatures obtained from all the spectra analyzed are shown in the Supplement. The Raman spectra were decomposed into bands following the appropriate fitting procedure described in Beyssac et al. (2002a) for the lower formations (high- temperature Raman spectra; ratio parameter R2) and Lahfid et al. (2010) for the Santa Iría Formation (low-temperature Raman spectra; ratio parameters RA1 and RA2; Fig. 3). The average temperatures are shown in Table 1 and Fig. 1c with a relative color bar from red (higher temperature) to blue (lower temperature). The average temperatures for the lower formations range from 420 to $530^{\circ} \mathrm{C}$, with a mean value of $468^{\circ} \mathrm{C}$ (standard deviation of 35 ). The highest temperatures are found in samples PLB-82 $\left(530^{\circ} \mathrm{C}\right)$ and PLB-93 $\left(495^{\circ} \mathrm{C}\right)$, and estimates of the remaining samples do not exceed $480^{\circ} \mathrm{C}$. As for the Santa Iría Formation, temperatures are lower $\left(315-330^{\circ} \mathrm{C}\right.$; Table 1$)$ than in the underlying formations.

\section{Interpretation and discussion}

\subsection{Deformation-metamorphism relationships}

The obtained analytical results are interpreted below in the context of the Variscan evolution of the Pulo do Lobo domain. As described above, two regional deformational events, $D_{1}$ and $D_{2}$, yielded two foliations (Devonian $S_{1}$ and 
Carboniferous $S_{2}$ ) accompanied by metamorphic phyllosilicate growth $\left(M_{1}\right.$ and $\left.M_{2}\right)$. In the cross sections in Fig. 1c, KI values derived from XRD and average temperature from RSCM suggest that the lowest metamorphic grade (green and blue) corresponds to the Santa Iría Formation.

Textural observations suggest that in most samples of the lower formations $M_{1}$ was the main crystallization event, developing abundant and large-sized white mica and chlorite in $S_{1}$ microlithons, while $M_{2}$ generated small-sized white mica (e.g., Fig. 2e and map 1 in Fig. 4). On the other hand, polydeformed rocks commonly show previously grown minerals rotated towards a new foliation developed at lower-grade conditions, without new crystallization. This could be the case of the white micas that define $S_{2}$ in some samples (illustrated in Fig. 2d), which, in turn, is compatible with the similar chemical composition of $S_{1}$ and $S_{2}$ micas (Fig. 5a). As shown in these samples, $S_{1}$ is variably crenulated by $D_{2}$, implying that $M_{1}$ minerals are variably rotated towards $S_{2}$. Consequently, the metamorphic data obtained from the samples of the lower formations will be ascribed to $D_{1}-M_{1}$. Sample PLB-93 might represent an exception, since its slightly higher RSCM and chlorite-derived temperatures could be due to nearby intrusions (Fig. 1b and 1c2; see below). In this respect, it is important to note the Mississippian transtensional event (basin development and abundant mafic magmatism) that took place between $D_{1}$ and $D_{2}$ (Pérez-Cáceres et al., 2015). The characterization of $M_{2}$ can be done by studying the samples from the Santa Iría Formation, which are only affected by $S_{2}$ accompanied by small-sized phyllosilicate growth (Fig. 2f). No crystallization has been observed related to the $S_{3}$ disjunctive crenulation cleavage.

\subsection{First tectonothermal event (Devonian $M_{1}$ )}

The observed mineral assemblage $(\mathrm{Qz}+\mathrm{Ab}+\mathrm{Ms}+\mathrm{Chl} \pm$ $\mathrm{Pg}$ ), together with the presence of $\mathrm{C}-\mathrm{S}$, is compatible with low-grade metamorphic conditions (Table 1). White mica crystallinity values $\left(0.17-0.22 \Delta^{\circ} 2 \theta\right.$; average 0.19$)$ are consistently in the range of the epizone (low-grade or greenschists facies; $>300^{\circ} \mathrm{C}$; Frey, 1987; Kisch, 1987; Warr and Ferreiro Mähnlmann, 2015), in accordance with the values reported by Abad et al. (2001) in a more general study of the diagenetic-metamorphic evolution of the South Portuguese Zone metapelites. Nevertheless, both the values of $\mathrm{KI}$, far from $0.14 \Delta^{\circ} 2 \theta$ (high epizone conditions according to Abad et al., 2006), and their variability, suggest that temperature was not high enough to stabilize a highly crystalline white mica. This interpretation is in agreement with the low Na content of K-micas coexisting with paragonite (Fig. 6), implying a very low-temperature position in the muscovite-paragonite solvus for natural quasi-binary $\mathrm{Pg}-\mathrm{Ms}$ pairs (Guidotti et al., 1994). By contrast, the maximum temperatures obtained from RSCM geothermometry are surprisingly high $\left(420-530^{\circ} \mathrm{C}\right.$; average $470^{\circ} \mathrm{C}$; corresponding to very high epizone or even medium-grade metamorphic conditions; Table 1).

The composition of paired chlorite and white mica is normally used to calculate pressure and temperature (e.g., Vidal et al., 2006), but the multi-equilibrium approach was not successful because the $P-T$ equilibrium conditions did not converge. This result is indicative of chemical disequilibrium, precluding their use as a reliable geothermobarometer in this case. The temperatures calculated from chlorite compositions following various approaches (Vidal et al., 2006, Fig. 7a; Bourdelle et al., 2013, Fig. 7b; Lanari et al., 2014a, Fig. 4d) are as follows: $100-230^{\circ} \mathrm{C}$ for sample PLB-88, 150 $375^{\circ} \mathrm{C}$ for sample PLB-84, and $150-450^{\circ} \mathrm{C}$ for sample PLB93 (Figs. 4d and 7, and Table 1). The slightly higher temperature of sample PLB-93 is inferred from its highest white mica crystallinity $\left(0.17 \Delta^{\circ} 2 \theta\right)$, high RSCM temperature $\left(495^{\circ} \mathrm{C}\right)$, high-temperature (amesite-rich) chlorite, and higher chlorite thermometry (Table 1); this can be explained by its proximity to metric-scale mafic igneous bodies of the Peramora Mélange (located $\approx 200 \mathrm{~m}$ to the south; Pérez-Cáceres et al., 2015 ) and/or to a granite stock (located $\approx 5 \mathrm{~km}$ to the west) (Fig. 1b).

In our samples there is some evidence of chlorite retrogression: (i) the chemical disequilibrium shown by the white mica-chlorite geothermobarometer, (ii) the presence of $\mathrm{C}-\mathrm{S}$ mixed layers that are not stable in the epizone (e.g., Potel et al., 2006), (iii) the difference between temperature estimates from crystal rims to cores and the higher temperature relic cores preserved in large chlorites defining $S_{1}$ (Fig. 4c-d), and (iv) the previously reported XRD and TEM data for chlorite retrograded to smectite and corrensite in the Pulo do Lobo domain (see Fig. 1 in Nieto et al., 2005). The existence of chlorites with different compositions crystallized at different temperatures is the typical scenario (e.g., Vidal et al., 2006, 2016; Lanari et al., 2012, 2014a, b; Grosch et al., 2012, 2014; Cantarero et al., 2014). In such situations, precise estimates of a single temperature and pressure attributable to peak conditions are really difficult to obtain. The maximum temperature shown by chlorite relic cores is $350-450{ }^{\circ} \mathrm{C}$ (Fig. $4 \mathrm{~d}$ ), which is consistent with the conditions estimated for $M_{1}$ by means of RSCM data.

An issue that deserves some discussion is the difference in temperature estimates between RSCM and other techniques. RSCM thermometry records the peak temperature and is not sensitive to the retrograde path. Alternatively, other methods based on phyllosilicate compositions are prone to record re-equilibration during the retrograde path; thus, they rarely record the peak conditions, except perhaps in the core of certain large crystals. Therefore, RSCM and phyllosilicatebased methods do not record the same information on temperature but are in fact complementary. The analyzed CM grains were carefully checked by microtextural observations and spectral geometry to ensure that these grains were actually derived from in situ organic matter graphitized during metamorphism. 
Table 2. Summary of the tectonometamorphic Variscan evolution of the Pulo do Lobo domain.

\begin{tabular}{|c|c|c|c|}
\hline Time & $\begin{array}{l}\text { Deformation/ } \\
\text { metamorphic } \\
\text { phase }\end{array}$ & Temperature & $\begin{array}{l}\text { Low-grade } \\
\text { metamorphic } \\
\text { conditions }\end{array}$ \\
\hline Middle-upper & $S_{3}$ & - & - \\
\hline Carboniferous & $S_{2}-M_{2}$ & $<300^{\circ} \mathrm{C}$ & Epizone-anchizone limit \\
\hline $\begin{array}{l}\text { Early Carboniferous } \\
(\sim 340 \mathrm{Ma})\end{array}$ & \multicolumn{3}{|c|}{$\begin{array}{c}\text { Beja-Acebuches and Pulo do Lobo metamafics } \\
\text { thermal imprint }\end{array}$} \\
\hline Upper Devonian & $S_{1}-M_{1}$ & $\sim 300-450^{\circ} \mathrm{C}$ & Epizone \\
\hline
\end{tabular}

In our case study, at the high peak temperature given by the RSCM thermometry, minerals such as biotite and garnet are expected to crystallize in metasedimentary rocks, though they were not observed in our samples. Biotite has been said to exist in a few previous works (Apalategui et al., 1983; Braid et al., 2010; Rubio Pascual et al., 2013). However, in a few of our samples, biotite-looking crystals turned out to be oxichlorites under SEM analyses. The absence or exceptional presence of biotite can be due to whole-rock composition and explained by growth inhibition related to Na excess, as evidenced by the presence of albite and paragonite in our samples. Another possible explanation could be the higher sensitivity of CM graphitization to rapid re-equilibration during a short-duration thermal event. Thus, the Mississippian intrusions subsequent to $M_{1}$ in the Pulo do Lobo Formation (see the description in Sect. 2) could have exerted a fast and locally intense thermal imprint that influenced CM but not the crystal chemistry of silicates. Moreover, recrystallization processes are not only a function of temperature, but are also promoted by deformation and stress, time, and the fluid to rock ratio (Merriman and Frey, 1999). Observations of this kind (differing reaction kinetics between organic and inorganic material, e.g., illite) in a contact metamorphic setting can be found in Olsson (1999) and Abad et al. (2014). Regarding the timing of geological processes, Mori et al. (2017) investigated the importance of heating duration for RSCM thermometry by studying graphitization around dykes. They showed that small-scale intrusions generating short thermal events modify the structure of $\mathrm{CM}$ in the surrounding rocks and concluded that CM crystallinity is clearly related to contact metamorphism. The influence of low-pressure contact aureoles on RSCM temperature patterns is further supported by the results obtained by Hilchie and Jamieson (2014), who concluded that the variation of RSCM temperatures can be controlled by the subsurface geometry of a pluton. Finally, the long-distance thermal influence of plutonic intrusions on low-grade rocks located as far as $10 \mathrm{~km}$ has already been documented (e.g., Merriman and Frey, 1999; Martínez Poyatos et al., 2001) and was also recorded by RSCM thermometry in our samples.

\subsection{Second tectonothermal event (middle-upper Carboniferous $\mathrm{M}_{2}$ )}

The mineralogy of the Santa Iría samples $(\mathrm{Qz}+\mathrm{Fsp}+\mathrm{Ms}+\mathrm{Chl} \pm \mathrm{C}-\mathrm{S})$ is compatible with verylow- to low-grade conditions. The K-white mica crystallinity values $\left(0.20-0.26 \Delta^{\circ} 2 \theta\right.$; average 0.23$)$ point to lower epizone conditions, very close to the boundary with the anchizone $\left(\approx 300^{\circ} \mathrm{C}\right.$; Frey, 1987; Kisch, 1987). The temperatures calculated by RSCM in two samples $\left(315\right.$ and $\left.330^{\circ} \mathrm{C}\right)$ are compatible with the KI data from XRD analysis.

Our metamorphic data corroborate the existence of an unconformity between the lower and upper formations of the Pulo do Lobo domain (Pérez-Cáceres et al., 2015). Table 2 summarizes the relationship between the deformation and metamorphism of the Pulo do Lobo domain in the context of the Variscan tectonic evolution of SW Iberia (PérezCáceres et al., 2015). The lower formations record a Devonian tectonothermal event that reached epizone or lower greenschist facies conditions ( $M_{1}$ with generalized phyllosilicate growth at temperatures as high as $450{ }^{\circ} \mathrm{C}$ ), whereas the overlying upper formation records a middle-upper Carboniferous tectonothermal event close to the anchizone-epizone boundary ( $M_{2}$ with small-sized phyllosilicate growth at temperatures $\approx 300-330{ }^{\circ} \mathrm{C}$; Table 1 ). Obviously, $M_{2}$ also affected somehow the lower formations, being, at least in part, the responsible for the observed retrogression of $M_{1}$ chlorite and/or crystallization of new chlorites at lower temperature.

\subsection{Pressure conditions}

The measured $b$-cell parameters of K-white mica (in a short range between 8.991 and $9.002 \AA$; average 8.996; standard deviation 0.003 ) are very similar in the lower and upper formations of the Pulo do Lobo domain. Thus, the $b$ parameter shows little variation and reflects very low phengite substitution in mica, as expected in low-pressure settings (Potel et al., 2006, 2016) near the intermediate pressure gradient boundary (Guidotti and Sassi, 1986).

In agreement with the low $b$-cell parameters, the composition of K-white mica is close to muscovite with very low celadonite and higher pyrophyllite content (Fig. 5a), as ex- 
pected for illite-rich mica formed at low-pressure gradients. In the case of high- or medium-pressure conditions, a continuous trend in mica compositions would reflect the decompression path after the peak pressure, while the $b$-cell parameter would represent an average value of the range of mica compositions found in the sample (Abad et al., 2003b). In contrast, in low-pressure settings, the overall range of recorded pressure is very restricted, and micas present similar compositions and $b$-cell parameters among the various samples, as in the case of the Pulo do Lobo samples (Figs. 5a and 6, Table 1).

The Pulo do Lobo domain has been classically interpreted as a pre-collisional subduction-related accretionary prism based on the MORB geochemistry of mafic rocks (see Sect. 2.1). According to this classical interpretation, features typical of modern subduction systems should be expected, such as high-pressure metamorphic gradient remnants of partial subduction-exhumation in an accretionary wedge (e.g., Platt, 1986; Ernst, 2005) or slices of oceanic slab-derived lithologies (varied mid-ocean ridge meta-igneous lithologies and also deep ocean bottom metasediments). Thus, recent works on the Makran accretionary prism (Omrani et al., 2017) and the subduction system of Japan (Endo and Wallis, 2017) describe an accretionary mélange complex composed of pelagic sedimentary rocks, ophiolites, greenschists, amphibolites, and blueschists with high-pressure minerals such as lawsonite and glaucophane. However, most of the geological data concerning the Pulo do Lobo domain do not support such an interpretation (see Sect. 2.1), and our new estimates of pressure conditions are also in disagreement. The only evidence supporting a high-pressure gradient in the Pulo do Lobo domain is the interpretation of some rhomboidal aggregates of epidote porphyroblasts as the remnants of supposed lawsonite grown prior to $S_{2}$ in some samples in the Pulo do Lobo mafic schists (Rubio Pascual et al., 2013). However, no analytical data have been presented to support the presence of lawsonite pseudomorphs.

\section{Conclusions}

A total of 18 samples of metapelites from the Pulo do Lobo domain have been studied to determine their Variscan lowgrade metamorphic conditions. The microstructural analysis of the samples of the lower formations (Devonian Pulo do Lobo and Ribeira de Limas) shows the existence of two superposed low-grade tectonothermal events with associated foliation and phyllosilicate growth $\left(S_{1}-M_{1}\right.$ and $S_{2}-M_{2}$; Table 2). $M_{2}$ was less intense and is the only event that affected the overlying Carboniferous Santa Iría Formation. The regional geology also shows that a Mississippian thermal (magmatic) event occurred between $M_{1}$ and $M_{2}$.

$M_{1}$ and $M_{2}$ correspond to chlorite zone metamorphism, but $M_{1}$ attained epizone conditions (greenschists facies with temperatures up to $\approx 450{ }^{\circ} \mathrm{C}$ ), while $M_{2}$ did not exceed the anchizone-epizone boundary $\left(\approx 300^{\circ} \mathrm{C}\right)$.

The temperature estimates obtained from RSCM are higher than the estimates obtained from chlorite geothermometry and white mica data. This discrepancy can be explained by the fact that RSCM records the maximum temperature because it is not affected by retrogression, in contrast to the other methods. In addition, this difference could be the consequence of the high sensitivity of CM to quickly re-equilibrating to maximum temperatures during short-duration thermal events such as the magmatic intrusions emplaced during the Mississippian thermal event.

Thermodynamic disequilibrium between white mica and chlorite has precluded their use for geothermobarometry, and a variety of data (including the existence of relic hightemperature chlorite cores, the presence of chlorite-smectite mixed layers, or the very low temperature calculated with chlorite geothermometers) indicate chlorite retrogression after the $M_{1}$ metamorphic climax and crystallization of new chlorite grains at lower temperature.

The low-pressure conditions derived from white mica indicators (very low celadonite content and $b$-cell values) are incompatible with the high-pressure metamorphic gradient expected in a subduction-related accretionary wedge, which has been the classical interpretation of the Pulo do Lobo domain. Instead, we interpret the Pulo do Lobo rocks as having been deposited in a platform setting located near the northern border of Avalonia, but they were never involved in the subduction-related processes of the SPZ-OMZ suture.

Data availability. The software and models used are available in the bibliography. The RSCM data set is given in Supplement.

Supplement. The supplement related to this article is available online at: https://doi.org/10.5194/se-11-469-2020-supplement.

Author contributions. IPC and DJMP collected the samples. IPC, $\mathrm{OV}, \mathrm{OB}$ and FN did the analysis. All the authors contributed to the interpretation of the results and writing of the paper: IPC, DJMP, JFS and AZ focused on the regional geology, and OV, OB, FN and FB on the methodologies used.

Competing interests. The authors declare that they have no conflict of interest.

Special issue statement. This article is part of the special issue "The Iberian Massif in the frame of the European Variscan Belt". It is not associated with a conference. 
Acknowledgements. We thank Valérie Magnin for her assistance with the microprobe analysis in Grenoble and Pierre Lanari for his support with thermodynamic software. Detailed revisions by Cecilio Quesada, J. B. Murphy, and an anonymous reviewer contributed to improving this paper.

Financial support. This research has been supported by the Spanish Ministry of Science and Innovation (grant no. CGL2011-24101), the Spanish Ministry of Economy and Competitiveness (grant nos. CGL2015-71692-P, CGL2016-75679-P), the Andalusian Government (grant nos. RNM-148, RNM-179), and the doctoral scholarship to Irene Pérez-Cáceres from the Spanish Ministry of Science and Innovation (grant no. BES-2012-055754). The Raman facility in Paris has been funded by the city of Paris (Emergence program).

Review statement. This paper was edited by Emilio Clavijo and reviewed by Cecilio Quesada and one anonymous referee.

\section{References}

Abad, I., Mata, M. P., Nieto, F., and Velilla, N: The phyllosilicates in diagenetic-metamorphic rocks of the South Portuguese Zone, southwestern Portugal, The Canadian Mineralogist, 39, 15711589, 2001.

Abad, I., Nieto, F., and Velilla, N.: Chemical and textural characterisation of diagenetic to low-grade metamorphic phyllosilicates in turbidite sandstones of the South Portuguese Zone: A comparison between metapelites and sandstones, Schweiz. Miner. Petrog., 82, 303-324, 2002.

Abad, I., Nieto, F., and Gutiérrez-Alonso, G.: Textural and chemical changes in slate-forming phyllosilicates across the externalinternal zones transition in the low-grade metamorphic belt of the NW Iberian Variscan Chain, Swiss Bull. Miner. Petrol., 83, 63-80, 2003a.

Abad, I., Gutierrez-Alonso, G., Nieto, F., Gertner, I., Becker, A., and Cabero, A.: The structure and the phyllosilicates (chemistry, crystallinity and texture) of Talas Ala-Tau (Tien Shan, Kyrgyz Republic); comparison with more recent subduction complexes, Tectonophysics, 365, 103-127, 2003b.

Abad, I., Nieto, F., Gutiérrez-Alonso, G., Campo, M. D., LópezMunguira, A., and Velilla, N.: Illitic substitution in micas of very low-grade metamorphic clastic rocks, Eur. J. Mineral., 18, 5969, 2006.

Abad, I., Nieto, F., Velilla, N., and Suárez-Ruiz, I.: Metamorphic evidences from the Monchique pluton (South Portugal): Contact metamorphism vs regional metamorphism under very lowgrade conditions, Revista de la Sociedad Geológica de España, 27, 337-350, 2014.

Abalos, B., Gil Ibarguchi, J. I., and Eguiluz, L.: Cadomian subduction/collision and Variscan transpression in the Badajoz-Córdoba shear belt, southwest Spain, Tectonophysics, 199, 51-72, 1991.

Airaghi, L., Lanari, P., de Sigoyer, J., and Guillot, S.: Microstructural vs compositional preservation and pseudomorphic replacement of muscovite in deformed metapelites from the Longmen Shan (Sichuan, China), Lithos, 282, 262-280, 2017.
Ali, A.: The tectono-metamorphic evolution of the Balcooma Metamorphic Group, north-eastern Australia: a multidisciplinary approach, J. Metamorph. Geol., 28, 397-422, 2010.

Apalategui, O., Barranco, E., Contreras, F., Delgado, M., and Roldán, F. J.: Hoja 916, Aroche, Mapa Geológico de España a escala $1: 50000$, Inst. Geológico y Minero de España, Madrid, 1983.

Araújo, A., Fonseca, P., Munhá, J., Moita, P., Pedro, J., and Ribeiro, A.: The Moura Phyllonitic Complex: an accretionary complex related with obduction in the southern Iberia Variscan suture, Geodin. Acta, 18, 375-388, 2005.

Arenas, R., Abati, J., Martínez Catalán, J. R., García, F. D., and Pascual, F. R.: PT evolution of eclogites from the Agualada Unit (Ordenes Complex, northwest Iberian Massif, Spain): Implications for crustal subduction, Lithos, 40, 221-242, 1997.

Azor, A., González Lodeiro, F., and Simancas, J. F.: Tectonic evolution of the boundary between the Central Iberian and OssaMorena zones (Variscan Belt, southwest Spain), Tectonics, 13, 45-61, 1994.

Azor, A., Rubatto, D., Simancas, J. F., González Lodeiro, F., Martínez Poyatos, D., Martín Parra L. M., and Matas, J.: Rheic Ocean ophiolitic remnants in Southern Iberia questioned by SHRIMP U-Pb zircon ages on the Beja-Acebuches amphibolites, Tectonics, 27, TC5006, https://doi.org/10.1029/2008TC002306, 2008.

Azor, A., Simancas, J. F., Martínez Poyatos, D., Pérez-Cáceres, I., González Lodeiro, F., and Expósito, I.: Chapter 10.3: Deformation and Structure, Southwestern Iberia, in: The Geology of Iberia: A Geodynamic Approach, Volume 2: The Variscan Cycle, edited by: Quesada, C. and Oliveira, J. T., Springer, 316-335, 2019.

Barbero, L.: Granulite-facies metamorphism in the Anatectic Complex of Toledo, Spain: late Hercynian tectonic evolution by crustal extension, J. Geol. Soc., 152, 365-382, 1995.

Bard, J. P.: Signification tectonique des métatholeites d'anité abyssale de la ceinture de base pression d'Aracena (Huelva, Espagne), B. Soc. Geol. Fr., 19, 385-393, 1977.

Bastida, F., Martínez-Catalán, J. R., and Pulgar, J. A.: Structural, metamorphic and magmatic history of the Mondoñedo nappe (Hercynian belt, NW Spain), J. Struct. Geol., 8, 415-430, 1986.

Bastida, F., Brime, C., García-López, S. Aller, J., Valin, M. L., and Sanz-López, J.: Tectono-thermal evolution of the Cantabrian Zone (NW Spain), in: Palaeozoic conodonts from northern Spain, edited by: García López, S., and Bastida, F., Instituto Geológico y Minero de España, Cuadernos del Museo Geominero, 1, Madrid, 105-123, 2002.

Battaglia, S., Leoni, L., and Sartori, F.: The Kübler index in late diagenetic to low-grade metamorphic pelites: a critical comparison of data from $10 \AA$ and $5 \AA$ peaks, Clay. Clay Miner., 52, 85-105, 2004.

Beyssac, O., Goffé, B., Chopin, C., and Rouzaud, J. N.: Raman spectra of carbonaceous material in metasediments: a new geothermometer, J. Metamorph. Geol., 20, 859-871, 2002a.

Beyssac, O., Rouzaud, J.-N., Goffé, B., Brunet, F., and Chopin, C.: Graphitization in a high-pressure, low temperature metamorphic gradient: a Raman microspectroscopy and HRTEM study, Contrib. Mineral. Petrol., 143, 19-31, 2002b.

Beyssac, O., Goffé, B., Petitet, J. P., Froigneux, E., and Rouzaud, J. N.: On the characterization of disordered and heterogeneous 
carbonaceous materials using Raman spectroscopy, Spectrochim, Acta A Mol. Biomol. Spectrosc., 59, 2267-2276, 2003.

Beyssac, O., Bollinger, L., Avouac, J. P., and Goffé, B.: Thermal metamorphism in the lesser Himalaya of Nepal determined from Raman spectroscopy of carbonaceous material, Earth Planet. Sc. Lett., 225, 233-241, 2004.

Booth-Rea, G., Simancas, J. F., Azor, A., Azañón, J. M., Gonzalez Lodeiro, F., and Fonseca, P.: HP-LT Variscan metamorphism in the Cubito-Moura schists (Ossa-Morena Zone, southern Iberia), C. R. Geosci., 338, 1260-1267, 2006.

Bourdelle, F., Parra, T., Chopin, C., and Beyssac, O.: A new chlorite geothermometer for diagenetic to low-grade metamorphic conditions, Contrib. Mineral. Petr., 165, 723-735, 2013.

Bousquet, R., Oberha, R., Goffé, B., Wiederkehr, M., Koller, F., Schmid, S. M., Schuster, R., Engi, M., Berger, A., and Martinotti, G.: Metamorphism of metasediments at the scale of an orogen: a key to the tertiary geodynamic evolution of the Alps, Geol. Soc. Lond. Spec. Publ., 298, 393-411, 2008.

Braid, J. A., Murphy, J. B., and Quesada, C.: Structural analysis of an accretionary prism in a continental collisional setting, the Late Paleozoic Pulo do Lobo Zone, Southern Iberia, Gondwana Res., 17, 422-439, 2010.

Braid, J. A., Murphy, J. B., Quesada, C., and Mortensen, J.: Tectonic escape of a crustal fragment during the closure of the Rheic Ocean: U-Pb detrital zircon data from the Late Palaeozoic Pulo do Lobo and South Portuguese zones, southern Iberia, J. Geol. Soc., 168, 383-392, 2011.

Braid, J. A., Murphy, J. B., Quesada, C., Gladney, E. R., and Dupuis, N.: Progressive magmatism and evolution of the Variscan suture in southern Iberia, Int. J. Earth Sci., 107, 971-983, 2018.

Brown, M.: P-T-t evolution of orogenic belts and the causes of regional metamorphism, J. Geol. Soc., 150, 227-241, 1993.

Burg, J. P., Iglesias, M., Laurent, P., Matte, P., and Ribeiro, A.: Variscan intracontinental deformation: the Coimbra-Córdoba Shear zone (SW Iberian Peninsula), Tectonophysics, 78, 161$177,1981$.

Cantarero, I., Lanari, P., Vidal O., Alías, G., Travé, A., and Baqués, V.: Long-term fluid circulation in extensional faults in the central Catalan Coastal Ranges: P-T constraints from neoformed chlorite and $K$-white mica, Int. J. Earth Sci., 103, 165-188, 2014.

Castro, A., Fernández, C., De la Rosa, J. D., Moreno Ventas, I., and Rogers, G.: Significance of MORB-derived amphibolites from the Aracena metamorphic belt, southwest Spain, J. Petrol., 37, 235-260, 1996.

Castro, A., Fernández, C., El-Hmidi, H., El-Biad, M., Díaz, M., De la Rosa, J., and Stuart, F.: Age constraints to the relationships between magmatism, metamorphism and tectonism in the Aracena metamorphic belt, southern Spain, Int. J. Earth Sci., 88, 26-37, 1999.

Cathelineau, M.: Cation site occupancy in chlorites and illites as a function of temperature, Clay Miner., 23, 471-485, 1988.

Cathelineau, M. and Nieva, D.: A chlorite solid solution geothermometer the Los Azufres (Mexico) geothermal system, Contrib. Mineral Petrol., 91, 235-244, 1985.

Coggon, R. and Holland, T. J. B.: Mixing properties of phengitic micas and revised garnet-phengite thermobarometers, J. Metamorph. Geol., 20, 683-696, 2002.

Crespo-Blanc, A.: Evolución geotectónica del contacto entre la zona de Ossa-Morena y la zona Surportuguesa en las sierras de Aracena y Aroche (Macizo Ibérico Meridional): Un contacto mayor en la cadena Hercínica Europea, Ph.D. Thesis, Univ. de Granada, 327 pp., 1991.

Crespo-Blanc, A. and Orozco, M.: The Southern Iberian Shear Zone: a major boundary in the Hercynian folded belt, Tectonophysics, 148, 221-227, 1988.

Crouzet, C., Dunkl, I., Paudel, L., Arkai, P., Rainer, T. M., Balogh, K., and Appel, E.: Temperature and age constraints on the metamorphism of the Tethyan Himalaya in Central Nepal: A multidisciplinary approach, J. Asian Earth Sci., 30, 113-130, 2007.

Dahn, D. R. L., Braid, J. A., Murphy, J. B., Quesada, C., Dupuis, N., and McFarlane, C. R. M.: Geochemistry of the Peramora Melange and Pulo do Lobo schist: Geochemical investigation and tectonic interpretation of mafic melange in the Pangean suture zone, Southern Iberia, I. J. Earth Sci., 103, 1415-1431, 2014

Dallmeyer, R. D., Fonseca, P. E., Quesada, C., and Ribeiro, A.: ${ }^{40} \mathrm{Ar} /{ }^{39} \mathrm{Ar}$ mineral age constraints for the tectonothermal evolution of a variscan suture in Southwest Iberia, Tectonophysics, 222, 177-194, 1993.

De Andrade, V., Vidal, O., Lewin, E., O'Brien, P., and Agard, P.: Quantification of electron microprobe compositional maps of rock thin sections: an optimized method and examples, J. Metamorph. Geol., 24, 655-668, 2006.

Díaz Azpiroz, M., Fernández, C., Castro, A., and El-Biad, M.: Tectonometamorphic evolution of the Aracena metamorphic belt (SW Spain) resulting from ridge-trench interaction during Variscan plate convergence, Tectonics, 25, TC1001, https://doi.org/10.1029/2004TC001742, 2006.

Eden, C. P.: Tectonostratigraphic analysis of the northern extent of the oceanic exotic terrane, Northwestern Huelva Province, Spain, Ph. D. Thesis, Univ. Southampton, 214 pp., 1991.

Eden, C. and Andrews, J.: Middle to upper Devonian melanges in SW Spain and their relationship to the Meneage formation in south Cornwall, Proc. Ussher Soc., 7, 217-222, 1990.

Endo, S. and Wallis, S. R.: Structural architecture and low-grade metamorphism of the Mikabu-Northern Chichibu accretionary wedge, SW Japan, J. Metamorph. Geol., 35, 695-716, 2017.

Ernst, W. G.: Tectonic history of subduction zones inferred from retrograde blueschist PT paths, Geology, 16, 1081-1084, 1988.

Ernst, W. G.: Alpine and Pacific styles of Phanerozoic mountain building: subduction-zone petrogenesis of continental crust, Terra Nova, 17, 165-188, 2005.

Escuder Viruete, J., Arenas, R., and Martínez Catalán, J.R.: Tectonothermal evolution associated with Variscan crustal extension in the Tormes gneiss dome (NW Salamanca, Iberian Massif, Spain), Tectonophysics, 238, 117-138, 1994.

Fonseca, P. and Ribeiro, A.: Tectonics of the Beja-Acebuches ophiolite - a major suture in the Iberian variscan foldbelt, Geol Rundsch., 82, 440-447, 1993.

Fonseca, P., Munhá, J., Pedro, J., Rosas, F., Moita, P., Araujo, A., and Leal, N.: Variscan ophiolites and high-pressure metamorphism in southern Iberia, Ofioliti, 24, 259-268, 1999.

Franceschelli, M., Leoni, L., Memmi, I., and Puxeddu, M.: Regional distribution of Al-silicates and metamorphic zonation in the lowgrade Verrucano metasediments from the Northern Apennines, Italy, J. Metamorph. Geol., 4, 309-321, 1986.

Frey, M.: Very low-grade metamorphism of clastic sedimentary rocks, in: Low temperature metamorphism, edited by: Frey, M., Blackie, Glasgow, 9-58, 1987. 
Frey, M. and Robinson, D.: Low-Grade Metamorphism, Blackwell Science Ltd, Cambridge, 313 pp., 1999.

Gil Ibarguchi, J., Mendia, M., Girardeau, J., and Peucat, J. J.: Petrology of eclogites and clinopyroxene-garnet metabasites from the Cabo Ortegal Complex (northwestern Spain), Lithos, 25, 133$162,1990$.

Goffé, B. and Velde, B.: Contrasted metamorphic evolutions in thrusted cover units of the Briançonnais zone (French Alps): A model for the conservation of HP-LT metamorphic mineral assemblages, Earth Planet. Sc. Lett., 68, 351-360, 1984.

Grosch, E. G., Vidal, O., Abu-Alam, T., and McLoughlin, N.: P$\mathrm{T}$ constraints on the metamorphic evolution of the Paleoarchean Kromberg type-section, Barberton greenstone belt, South Africa, J. Petrol., 53, 513-545, 2012.

Grosch, E. G., McLoughlin, N., Lanari, P., Erambert, M., and Vidal, O.: Microscale mapping of alteration conditions and potential biosignatures in basaltic-ultramafic rocks on early Earth and beyond, Astrobiology, 14, 216-228, 2014.

Guidotti, C. V. and Sassi, F. P.: Classification and correlation of metamorphic facies series by means of muscovite $\mathrm{b}$ data from low-grade metapelites, Neues Jb. Miner. Abh., 153, 363-380, 1986.

Guidotti, C. V., Mazzoli, C., Sassi, F. P., and Blencoe, J. G.: Compositional controls on the cell dimensions of $2 \mathrm{M}_{1}$ muscovite and paragonite, Eur. J. Miner., 4, 283-297, 1992.

Guidotti, C. V., Sassi, F. P., Blencoe, J. G., and Selverstone, J.: The paragonite-muscovite solvus: I. P-T-X limits derived from the $\mathrm{Na}-\mathrm{K}$ compositions of natural, quasibinary paragonitemuscovite pairs, Geochim. Cosmochim. Ac., 58, 2269-2275, 1994.

Gutiérrez-Alonso, G. and Nieto, F.: White-mica "crystallinity”, finite strain and cleavage development across a large Variscan structure, NW Spain, J. Geol. Soc., 153, 287-299, 1996.

Hilchie, L. J. and Jamieson, R. A.: Graphite thermometry in a lowpressure contact aureole, Halifax, Nova Scotia, Lithos, 208, 2133, 2014.

Jarosewich, E. J., Nelen, J. A., and Norberg, J. A.: Reference samples for electron microprobe analysis, Geostandard. Newslett., 4, 43-47, 1980.

Kisch, H. J.: Correlation between indicators of very low-grade metamorphism, in: Low temperature metamorphism, edited by: Frey, M., Blackie, Glasgow, 227-300, 1987.

Kisch, H. J.: Illite crystallinity: recommendations on sample preparation, X-ray diffraction settings, and interlaboratory samples, J. Metamorph. Geol., 9, 665-670, 1991.

Kübler, B.: Evaluation quantitative du metamorphism par la cristallinite de l'Illite, Bull. Centres Rech. Pau-SNPA 2, 385397, 1968.

Lahfid, A., Beyssac, O., Deville, E., Negro, F., Chopin, C., and Goffé, B.: Evolution of the Raman spectrum of carbonaceous material in low-grade metasediments of the Glarus Alps (Switzerland), Terra Nova, 22, 354-360, 2010.

Lanari, P., Guillot, S., Schwartz, S., Vidal, O., Tricart, P., Riel, N., and Beyssac, O.: Diachronous evolution of the alpine continental subduction wedge: evidence from P-T estimates in the Briançonnais Zone houillère (France-Western Alps), J. Geodyn., 56/57, 39-54, 2012.

Lanari, P., Vidal, O., de Andrade, V., Dubacq, B., Lewin, E., Grosch, E. G., and Schwartz, S.: XMapTools: A MATLAB $\odot-$ based program for electron microprobe X-Ray image processing and geothermobarometry, Comput. Geosci., 62, 227-240, 2014a.

Lanari, P., Rolland, Y., Schwartz, S., Vidal, O., Guillot, S., Tricart, P., and Dumont, T.: P-T-t estimation of deformation in low-grade quartz-feldspar-bearing rocks using thermodynamic modelling and ${ }^{40} \mathrm{Ar} /{ }^{39} \mathrm{Ar}$ dating techniques: example of the Plan-de-Phasy shear zone unit (Briançonnais Zone, Western Alps), Terra Nova, 26, 130-138, 2014b.

Lopes, G., Pereira, Z., Fernandes, P., Wicander, R., Matos, J. X., Rosa, D., and Oliveira, J. T.: The significance of reworked palynomorphs (middle Cambrian to Tournaisian) in the Visean Toca da Moura Complex (South Portugal). Implications for the geodynamic evolution of Ossa Morena Zone, Rev. Palaeobot. Palynol., 200, 1-23, 2014.

López-Carmona, A., Pitra, P., and Abati, J.: Blueschist-facies metapelites from the Malpica-Tui Unit (NW Iberian Massif): phase equilibria modelling and $\mathrm{H}_{2} \mathrm{O}$ and $\mathrm{Fe}_{2} \mathrm{O}_{3}$ influence in high-pressure assemblages, J. Metamorph. Geol., 31, 263-280, 2013.

López Munguira, A., Nieto, F., Pardo, E. S., and Velilla, N.: The composition of phyllosilicates in Precambrian, low-grade metamorphic, clastic rocks from the Southern Hesperian Massif (Spain) used as an indicator to metamorphic conditions, Precambrian Res., 53, 267-279, 1991.

López Sánchez-Vizcaíno, V., Gómez Pugnaire, M. T., Azor, A., and Fernández Soler, J. M.: Phase diagram sections applied to amphibolites: a case study from the Ossa-Morena/Central Iberian Variscan suture (Southwestern Iberian Massif), Lithos, 68, 1-21, 2003.

Martínez Catalán, J. R.: Estratigrafia y estructura del Domo de Lugo (Sector Oeste de la Zona Asturoccidental-leonesa), Corpus Geol. Gallaeacie (2॰ Serie), 2, 1-291, 1985.

Martínez Catalán, J. R., Rubio Pascual, F. J., Díez Montes, A., Díez Fernández, R., Gómez Barreiro, J., Dias Da Silva, Í., González Clavijo, E., Ayarza, P., and Alcock, J. E.: The late Variscan HT/LP metamorphic event in NW and Central Iberia: relationships to crustal thickening, extension, orocline development and crustal evolution, Geol. Soc. Lond. Special Publ., 405, 225-247, 2014.

Martínez Poyatos, D., Nieto, F., Azor, A., and Simancas, J. F.: Relationships between very low-grade metamorphism and tectonic deformation: Examples from the southern Central Iberian Zone (Iberian Massif, Variscan Belt), J. Geol. Soc., 158, 953-968, 2001.

Martínez Poza, A. I., Martínez Poyatos, D., Simancas, J. F., and Azor, A.: La estructura varisca de la Unidad del Pulo do Lobo (SO del Macizo Ibérico) en las transversales de Aroche y Rosal de la Frontera (Huelva), Geogaceta, 52, 21-24, 2012.

Massonne, H. J. and Schreyer, W.: Phengite geobarometry based on the limiting assemblage with K-feldespar, phlogopite, and quartz, Contrib. Mineral. Petrol., 96, 212-224, 1987.

Massonne, H. J. and Szpurka, Z.: Thermodynamic properties of white micas on the basis of high-pressure experiments in the systems $\mathrm{K}_{2} \mathrm{O}-\mathrm{MgO}-\mathrm{Al}_{2} \mathrm{O}_{3}-\mathrm{SiO}_{2}-\mathrm{H}_{2} \mathrm{O}$ and $\mathrm{K}_{2} \mathrm{O}-\mathrm{FeO}-\mathrm{Al}_{2} \mathrm{O}_{3}-\mathrm{SiO}_{2}-$ $\mathrm{H}_{2} \mathrm{O}$, Lithos, 41, 229-250, 1997.

Matte, P.: The Variscan collage and orogeny (480-290 Ma) and the tectonic definition of the Armorica microplate: A review, Terra Nova, 13, 122-128, 2001. 
Merriman, R. J. and Frey, M.: Patterns of very low-grade metamorphism in metapelitic rocks, in: Low-grade metamorphism, edited by: Frey, M. and Robinson, D., Blackwell, Oxford, 61107, 1999.

Moita, P., Munhá, J., Fonseca, P., Pedro, J., Araújo, A., Tassinari, C., and Palacios, T.: Phase equilibria and geochronology of OssaMorena eclogites, Actas do XIV Semana de Gequímica/VIII Congresso de geoquímica dos Países de Língua Portuguesa, 2, 471-474, 2005.

Moore, D. M. and Reynolds Jr., R. C.: X-ray Diffraction and the Identification and Analysis of Clay Minerals, 2nd edition, Oxford University Press, Oxford, 378 pp., 1997.

Mori, H., Mori, N., Wallis, S., Westaway, R., and Annen, C.: The importance of heating duration for Raman CM thermometry: evidence from contact metamorphism around the Great Whin Sill intrusion, UK, J. Metamorph. Geol., 35, 165-180, 2017.

Munhá, J.: Metamorphic evolution of the south Portuguese/Pulo do Lobo zone, in: Pre-Mesozoic Geology of Iberia, edited by: Dallmeyer, R. D. and Martínez García, E., Springer, Berlin, Germany, 363-368, 1990.

Munhá, J., Oliveira, J. T., Ribeiro, A., Oliveira, V., Quesada, C., and Kerrich, R.: Beja-Acebuches ophiolite, characterization and geodynamic significance, Maleo, 2, p. 31, 1986.

Murphy, J. B., Quesada, C., Gutiérrez-Alonso, G., Johnston, S. T., and Weil, A.: Reconciling competing models for the tectonostratigraphic zonation of the Variscan orogen in Western Europe, Tectonophysics, 681, 209-219, 2016.

Nieto, F. and Sánchez-Navas, A.: A comparative XRD and TEM study of the physical meaning of the white mica "crystallinity" index, Eur. J. Mineral., 6, 611-621, 1994.

Nieto, F., Mata, M. P., Bauluz, B., Giorgetti, G., Árkai, P., and Peacor, D.R.: Retrograde diagenesis, a widespread process on a regional scale, Clay Miner., 40, 93-104, 2005.

Oliveira, J. T.: Part VI: South Portuguese Zone, stratigraphy and synsedimentary tectonism, in: Pre-Mesozoic Geology of Iberia, edited by: Dallmeyer, R. D., and Martínez García, E., Springer, Berlin, Germany, 334-347, 1990

Olsson, I.: Regional burial heating vs. local magmatic heat influence of the Röstånga area, Scania, southern Sweden, GFF, J. Geol. Soc. Sweden, 121, 209-214, 1999.

Omrani, H., Moazzen, M., Oberhänsli, R., and Moslempour, M. E.: Iranshahr blueschist: subduction of the inner Makran oceanic crust, J. Metamorph. Geol., 35, 373-392, 2017.

Ordóñez-Casado, B.: Geochronological studies of the Pre-Mesozoic basement of the Iberian Massif: the Ossa-Morena Zone and the Allochthonous Complexes within the Central Iberian Zone, Ph.D. Thesis, ETH Zurich, 235 pp., 1998.

Parra, T., Vidal, O., and Agard, P.: A thermodynamic model for $\mathrm{Fe}-\mathrm{Mg}$ dioctahedral $\mathrm{K}$ White micas using data from phaseequilibrium experiments and natural pelitic assemblages, Contrib. Mineral Petrol., 143, 706-732, 2002.

Pedro, J., Araujo, A., Fonseca, P., Tassinari, C., and Ribeiro, A.: Geochemistry and U-Pb Zircon Age of the Internal Ossa-Morena Zone Ophiolite Sequences: A Remnant of Rheic Ocean in SW Iberia, Ofioliti, 35, 117-130, 2010.

Pereira, M. F., Chichorro, M., Williams, I. S., Silva, J. B., Fernández, C., Díaz-Azpíroz, M., Apraiz, A., and Castro, A.: Variscan intra-orogenic extensional tectonics in the Ossa-Morena Zone (Évora-Aracena-Lora del Río metamorphic belt, SW Iberian
Massif): SHRIMP zircon U-Th-Pb geochronology, Geol. Soc. Lond. Spec. Publ., 327, 215-237, 2009.

Pereira, M. F., Apraiz, A., Chichorro, M., Silva, J. B., and Armstrong, R. A.: Exhumation of high pressure rocks in northern Gondwana during the Early Carboniferous (Coimbra-Cordoba shear zone, SW Iberian Massif): tectonothermal analysis and UTh-Pb SHRIMP in-situ zircon geochronology, Gondwana Res., 17, 440-460, 2010.

Pereira, M. F., Chichorro, M., Silva, J. B., Ordóñez-Casado, B., Lee, J. K., and Williams, I. S.: Early carboniferous wrenching, exhumation of high-grade metamorphic rocks and basin instability in SW Iberia: constraints derived from structural geology and U$\mathrm{Pb}$ and ${ }^{40} \mathrm{Ar}-{ }^{39} \mathrm{Ar}$ geochronology, Tectonophysics, 558, 28-44, 2012.

Pereira, M. F., Martínez Poyatos, D., Pérez-Cáceres, I., Gama, C., and Azor, A.: Comment on "Stratigraphy of the Northern Pulo do Lobo Domain, SW Iberia Variscides: A palynological contribution" by Pereira, Z. et al. (2018), Geobios, 51, 491-506, 2019.

Pereira, Z., Matos, J., Fernandes, P., and Oliveira, J. T.: Palynostratigraphy and systematic palynology of the Devonian and Carboniferous successions of the South Portuguese Zone, Portugal, Memórias Geológicas do Instituto Nacional de Engenharia, Tecnologia e Inovaçao 34, Lisboa, 181 pp., 2008.

Pereira, Z., Fernandes, P., Matos, J., Jorge, R., and Oliveira, J. T.: Stratigraphy of the Northern Pulo do Lobo Domain, SW Iberia Variscides: A palynological contribution, Geobios, 51, 491-506, 2018.

Pérez-Cáceres, I., Martínez Poyatos, D., Simancas, J. F., and Azor, A.: The elusive nature of the Rheic Ocean in SW Iberia, Tectonics, 34, 2429-2450, 2015.

Pérez-Cáceres, I., Simancas, J. F., Martínez Poyatos, D., Azor, A., and González Lodeiro, F.: Oblique collision and deformation partitioning in the SW Iberian Variscides, Solid Earth, 7, 857-872, https://doi.org/10.5194/se-7-857-2016, 2016.

Pérez-Cáceres, I., Martínez Poyatos, D., Simancas, J. F., and Azor, A.: Testing the Avalonian affinity of the South Portuguese Zone and the Neoproterozoic evolution of SW Iberia through detrital zircon populations, Gondwana Res., 42, 177-192, 2017.

Pérez-Estaún, A., Bea, F., and Vera, J. A.: Macizo Ibérico, edited by: Vera, J. A., Geología de España, 19-228, 2004.

Petschick, R.: Software MacDiff, https://www.uni-frankfurt.de/ 69528130/Petschick__MacOS_ (last access: 26 March 2020), 2004.

Platt, J. P.: Dynamics of orogenic wedges and the uplift of highpressure metamorphic rocks, Geol. Soc. Am. Bull., 97, 10371053, 1986.

Ponce, C., Simancas, J. F., Azor, A., Martínez Poyatos, D. J., BoothRea, G., and Expósito, I.: Metamorphism and kinematics of the early deformation in the Variscan suture of SW Iberia, J. Metamorph. Geol., 30, 625-638, 2012.

Potel, S., Ferreiro-Mählmann, R., Stern, W. B., Mullis, J., and Frey, M.: Very low-grade metamorphic evolution of pelitic rocks under high-pressure/low-temperature conditions, NW New Caledonia (SW Pacific), J. Petrol., 47, 991-1015, 2006

Potel, S., Maison, T., Maillet, M., Sarr, A. C., Doublier, M. P., Trullenque, G., and Mählmann, R. F.: Reliability of very low-grade metamorphic methods to decipher basin evolution: Case study from the Markstein basin (Southern Vosges, NE France), Appl. Clay Sci., 134, 175-185, 2016. 
Quesada, C.: Geological constraints on the Paleozoic tectonic evolution of tectonostratigraphic terranes in the Iberian Massif, Tectonophysics, 185, 225-245, 1991.

Quesada, C., Fonseca, P. E., Munhá, J., Oliveira, J. T., and Ribeiro, A.: The Beja-Acebuches Ophiolite (Southern Iberia Variscan fold belt): geological characterization and significance, Boletín Geológico Minero, 105, 3-49, 1994.

Quesada, C., Braid, J. A., Fernandes, P., Ferreira, P., Jorge, R. S., Matos, J. X., Murphy, J. B., Oliveira, J. T., Pedro, J., and Pereira, Z.: SW Iberia Variscan Suture Zone: Oceanic Affinity Units, in: The Geology of Iberia: A Geodynamic Approach, Volume 2: The Variscan Cycle, edited by: Quesada, C. and Oliveira, J. T., Springer, 131-171, 2019.

Ribeiro, A., Munhá, J., Fonseca, P. E., Araujo, A., Pedro, J. C., Mateus, A., Tassinari, C., Machado, G., and Jesus, A.: Variscan ophiolite belts in the Ossa-Morena Zone (Southwest Iberia): Geological characterization and geodynamic significance, Gondwana Res., 17, 408-421, 2010.

Rubio Pascual, F. J., Matas, J., and Martín Parra, L. M.: Highpressure metamorphism in the Early Variscan subduction complex of the SW Iberian Massif, Tectonophysics, 592, 187-199, 2013.

Sassi, F. P. and Scolari, A.: The $b_{0}$ value of the potassic white micas as a barometric indicator in low-grade metamorphism of pelitic schists, Contrib. Mineral. Petr., 45, 143-152, 1974.

Silva, J. B., Oliveira, J. T., and Ribeiro, A.: South Portuguese Zone, structural outline, in: Pre-Mesozoic Geology of Iberia, edited by: Dallmeyer, R. D. and Martínez García, E., Springer, Berlin, Germany, 348-362, 1990.

Simancas, J. F., Carbonell, R., Lodeiro, F. G., Pérez-Estaún, A., Juhlin, C., Ayarza, P., Kashubin, A., Azor, A., Martínez Poyatos, D., Almodóvar, G. R., Pascual, E., Sáez, R., and Expósito, I.: Crustal structure of the transpressional Variscan orogen of SW Iberia: SW Iberia deep seismic reflection profile (IBERSEIS), Tectonics, 22, 1062, https://doi.org/10.1029/2002TC001479, 2003.
Simancas, J. F., Expósito, I., Azor, A., Martínez Poyatos, D., and González Lodeiro, F.: From the Cadomian orogenesis to the Early Palaeozoic Variscan rifting in Southwest Iberia, J. Iber. Geol., 30, 53-71, 2004.

Simancas, J. F., Carbonell, R., González Lodeiro, F., Pérez-Estaún, A., Juhlin, C., Ayarza, P., Kashubin, A., Azor A., Martínez Poyatos, D. J., Sáez, R., Almodóvar, G. R., Pascual R., Flecha, I., and Martí, D.: Transpressional collision tectonics and mantle plume dynamics: The Variscides of southwestern Iberia, Memoirs, Geol. Soc., 32, 345-354, 2006.

Vázquez, M., Abad, I., Jiménez-Millán, J., Rocha, F. T., Fonseca, P. E., and Chaminé, H. I.: Prograde epizonal clay mineral assemblages and retrograde alteration in tectonic basins controlled by major strike-slip zones (W Iberian Variscan chain), Clay Miner., 42, 109-128, 2007.

Vidal, O., Parra, T., and Vieillard, P.: Thermodynamic properties of the Tschermak solid solution in Fe-chlorite: application to natural examples and possible role of oxidation, Am. Mineral., 90, 347-358, 2005.

Vidal, O., de Andrade, V., Lewin, E., Muñoz, M., Parra, T., and Pascarelli, S.: P-T-deformation- $\mathrm{Fe}^{3+} / \mathrm{Fe}^{2+}$ mapping at the thin section scale and comparison with XANES mapping. Application to a garnet-bearing metapelite from the Sambagawa metamorphic belt (Japan), J. Metamorph. Geol., 24, 669-683, 2006.

Vidal, O., Lanari, P., Munoz, M., Bourdelle, F., and De Andrade, V.: Deciphering temperature, pressure and oxygen-activity conditions of chlorite formation, Clay Miner., 51, 615-633, 2016.

Warr, L. N. and Ferreiro Mählmann, R.: Recommendations for Kübler Index standardization, Clay Miner., 50, 283-286, 2015.

Warr, L. N. and Rice, A. H. N.: Inter-laboratory standardization and calibration of clay mineral crystallinity and crystallite size data, J. Metamorph. Geol., 12, 141-152, 1994.

Whitney, D. L. and Evans, B. W.: Abbreviations for names of rockforming minerals, Am. Mineral., 95, 185-187, 2010. 